\title{
The behaviour of giant clams (Bivalvia: Cardiidae: Tridacninae)
}

\author{
Pamela Soo $\cdot$ Peter A. Todd
}

Received: 2 July 2014 / Accepted: 12 September 2014 / Published online: 2 October 2014

(C) The Author(s) 2014. This article is published with open access at Springerlink.com

\begin{abstract}
Giant clams, the largest living bivalves, live in close association with coral reefs throughout the IndoPacific. These iconic invertebrates perform numerous important ecological roles as well as serve as flagship species-drawing attention to the ongoing destruction of coral reefs and their associated biodiversity. To date, no review of giant clams has focussed on their behaviour, yet this component of their autecology is critical to their life history and hence conservation. Almost 100 articles published between 1865 and 2014 include behavioural observations, and these have been collated and synthesised into five sections: spawning, locomotion, feeding, anti-predation, and stress responses. Even though the exact cues for spawning in the wild have yet to be elucidated, giant clams appear to display diel and lunar periodicities in reproduction, and for some species, peak breeding seasons have been established. Perhaps surprisingly, giant clams have considerable mobility, ranging from swimming and gliding as larvae to crawling in juveniles and adults. Chemotaxis and geotaxis have been established, but giant clams are not phototactic. At least one species exhibits clumping behaviour, which may enhance physical stabilisation, facilitate reproduction, or provide protection from predators. Giant clams undergo several shifts in their mode of acquiring nutrition; starting with a lecithotrophic and planktotrophic diet as larvae, switching to pedal feeding after metamorphosis followed by the transition to a dual mode of filter feeding and
\end{abstract}

Communicated by R. Hill.

P. Soo $\cdot$ P. A. Todd $(\bowtie)$

Experimental Marine Ecology Laboratory, Department

of Biological Sciences, National University of Singapore, 14 Science Drive 4, Blk S3 02-05, Singapore 117543, Singapore e-mail: dbspat@nus.edu.sg phototrophy once symbiosis with zooxanthellae (Symbiodinium spp.) is established. Because of their shell weight and/or byssal attachment, adult giant clams are unable to escape rapidly from threats using locomotion. Instead, they exhibit a suite of visually mediated anti-predation behaviours that include sudden contraction of the mantle, valve adduction, and squirting of water. Knowledge on the behaviour of giant clams will benefit conservation and restocking efforts and help fine-tune mariculture techniques. Understanding the repertoire of giant clam behaviours will also facilitate the prediction of threshold levels for sustainable exploitation as well as recovery rates of depleted clam populations.

\section{Introduction}

Giant clams (Bivalvia: Cardiidae: Tridacninae) are the largest living bivalves. They live in close association with coral reefs throughout the Indo-Pacific (Lucas 1988) where they are ecologically important as biomass for predators/scavengers and substrates for epibionts, in addition to physically contributing topographic relief (important as nurseries for fish) and calcium carbonate to the reef framework (Govan et al. 1993; Cabaitan et al. 2008; Accordi et al. 2010). Giant clams have also benefitted humans for millennia, through provision of food and materials (Hviding 1993). Unfortunately, harvesting for local consumption (Hester and Jones 1974), export of wild specimens for the aquarium trade (Wabnitz et al. 2003) and habitat degradation (Newman and Gomez 2000) have led to population declines (Alcala 1986; Braley 1987; Tan and Yasin 2003) and extirpations (Neo and Todd 2012a).

Giant clams are marine mollusc equivalents of 'charismatic megafauna' that can act as flagship taxa—drawing 
attention to the ongoing destruction of coral reefs and associated biodiversity. Hence, their conservation and study have a particular importance. Giant clam research has been reviewed a few times, with the primary emphases being their biology, nutrition and mariculture (e.g. Rosewater 1965; Munro and Heslinga 1983; Lucas 1994). No review of giant clams has focussed on their behaviour, yet this component of their autecology is critical to their life history and deserves attention. Here, we seek to address this gap by collating and, where possible, synthesising what is presently known regarding giant clam spawning, locomotion, feeding, anti-predation behaviour and stress responses. The effects of diseases or parasites on behaviour are not examined. We start by providing some phylogenetic and biological background on these iconic invertebrates.

\section{Tridacninae Lamarck, 1819}

Tridacninae currently compromises 12 extant species in two genera: Tridacna and Hippopus, i.e. T. gigas Linnaeus 1758; T. derasa Röding 1789; T. squamosa Lamarck 1819; Tridacna noae Röding 1798 (recently separated from T. maxima by $\mathrm{Su}$ et al. 2014); T. maxima Röding 1789; $T$. crocea Lamarck 1819; T. mbalavuana Ladd 1934; T. squamosina Sturany 1899 (previously known as T. costata); T. rosewateri Sirenko and Scarlato 1991; an undescribed cryptic Tridacna sp. (Huelsken et al. 2013); H. hippopus Linnaeus 1758; and H. porcellanus Rosewater 1982. The main differences between the two genera are that Hippopus have interlocking teeth at their byssal orifice (Lucas et al. 1991), and they open their valves further apart than Tridacna (Lucas 1994), but they do not extend their mantles laterally beyond their valve margins. These highly specialised bivalves are mainly distributed within the tropical Indo-Pacific region although three species, T. maxima, T. squamosa and T. squamosina, are found as far west as east Africa or the Red Sea (Rosewater 1965; Othman et al. 2010). Giant clams are markedly stenothermal and thus restricted to warm waters (Purchon 1977, p. 337). Typically living on sand or attached to coral rock and rubble by byssal threads, they are prominent inhabitants of coral reefsnot only due to their large size, but also because of their intricately patterned and pigmented mantle tissues (Yonge 1975; Calumpong 1992).

Similar to most other bivalves, giant clams are filter feeders. They pump water into their mantle cavity through an inhalant siphon and filter plankton using ciliated tracts on their gills (Hardy and Hardy 1969). The great size exhibited in giant clams cannot be achieved by these ctenidial feeding mechanisms alone (Purchon 1977); rather, it is accomplished together with symbiotic photosynthetic dinoflagellate algae, or zooxanthellae (genus Symbiodinium), that live within the mantle tissues (Kawaguti 1950,
1968). Zooxanthellae do not pass from one generation to another (LaBarbera 1975; Jameson 1976) and are permanently established only after metamorphosis from larva to juvenile (Fitt and Trench 1981).

Giant clams are protandrous hermaphrodites (Wada 1952), but otherwise follow the typical bivalve mollusc life cycle (Lucas 1994). Sperm is released, followed by eggs, into the water column where fertilisation takes place. Within a day, the embryo develops into a free-swimming trochophore larvae. Straight-hinge veligers $(\sim 160 \mu \mathrm{m})$ form by day two and develop a ciliated velum for locomotion and feeding. Transition to the pediveliger stage $(\sim 200 \mu \mathrm{m})$ over the next few days is marked by the formation of a foot and two-valved shells. During this stage, the pediveliger larvae crawl on the substrate in search of suitable sites for settlement and metamorphose into early juveniles (or spats) within 2 weeks of spawning (Ellis 1998; Blidberg 2004). Giant clams thus spend a short yet critical period of approximately 9 days as pelagic larvae compared to a much longer adult stage. The exact lifespan of tridacnines has not been ascertained, although it is estimated to vary between eight to several hundred years (Comfort 1957; Bonham 1965; Rosewater 1966). Contemporary giant clams do not commonly survive to great ages, possibly due to human activities that continue to threaten population numbers (Yamaguchi 1977; Guest et al. 2008).

Giant clams are distinct from their relatives in the family Cardiidae (cockles) due the unique rearrangement of their internal organs over evolutionary time. Rather than the hinge facing upwards (the normal position for cockles) and the foot protruding downwards, the hinge has rotated around the viscero-pedal mass so that it is on the underside (adjacent to the substrate) and aligned with the foot and byssal gape (Yonge 1975). This means that their enlarged dorsal siphonal mantle, that houses symbiotic zooxanthellae, is directed upwards towards the sunlight (Norton and Jones 1992). Their byssus is orientated downwards and used to attach the clam to hard coral reef substrates. Part of this rotation is reflected in their early ontogeny: although giant clam larvae go through typical bivalve veliger and pediveliger stages, they then undergo a transformation that results in the umbo and hinge positioned alongside the byssal gape (Yonge 1982). Giant clams still bear some similarities to other members of the Cardiidae, for example predator detection via chemoreception (e.g. in the common cockle Cerastoderma edule; Romano et al. 2011) and a photosymbiotic relationship (in some fragines, Kirkendale 2009; the heart cockle, Kawaguti 1950; and possibly in the heart/basket cockle Clinocardium nuttallii, Hartman and Pratt 1976), but they are behaviourally quite separate in many ways. As Yonge (1982, p. 770) notes: 'While basic structure, both of mantle/shell and viscero-pedal mass, indicates association with the Cardiidae..., the totally 
distinctive structure of the Tridacninae indicates long and intimate association with coral reefs'. This shallow, high irradiance habitat of giant clams has had profound effects on the evolution of their behaviour.

Giant clams serve various important roles in the coral reef ecosystem. Their calcium carbonate shells act as nurseries for fish (Cabaitan et al. 2008), as well as providing spatial refuge for smaller filter-feeding epibionts such as barnacles, polychaetes and sponges (Elfwing et al. 2003; Vicentuan-Cabaitan et al. 2014). Through their symbiotic relationship with zooxanthellae, giant clams not only contribute to reef productivity, but indirectly function as natural biofilters of dissolved nutrients (Mingoa-Licuanan and Gomez 2002). Throughout most of their geographical range, giant clams have traditionally been harvested for subsistence (food) and commercial (shell craft products) purposes but, more recently, demand by the aquarium trade has also placed a strain on their numbers (Mingoa-Licuanan and Gomez 2002; Soo et al. 2011). Illegal poaching, habitat degradation and reduced habitat range have substantially depleted giant clam populations, and local extinctions have been reported in the Philippines, Malaysia and Singapore (Alcala et al. 1986; Tan and Yasin 2001a; Guest et al. 2008; Neo and Todd 2012b). In addition, global climate change and associated high sea surface temperature events have led to giant clams 'bleaching' (i.e. the breaking down of the symbiotic relationship between the clam and their Symbiodinium) (Gomez and Mingoa-Licuanan 1998). Given the deleterious effects of human activities on their numbers worldwide, the trade of most giant clam species is currently regulated under Appendix II of the Convention of the International Trade of Endangered Species of Wild Flora and Fauna (CITES) (http://www.cites.org/). In an effort to conserve populations, many Indo-Pacific countries have restricted harvesting and developed mariculture for commercial purposes and the restocking of depleted reefs. Conservation strategies for these mega-invertebrates have become an important component of numerous coral reef management schemes (e.g. Gomez and Mingoa-Licuanan 2006; Neo and Todd 2012a).

\section{Giant clam research}

Taxonomic descriptions of Tridacninae date back to 1758 , but giant clam biology more generally escaped the attention of scientific research until the mid-nineteenth century (e.g. Vaillant 1865), perhaps surprising considering the evolutionary significance of the clam-zooxanthellae symbiosis (Brock 1888). In a bibliography of giant clam literature (Munro and Nash 1985), more than $70 \%$ of the scientific papers compiled were published after 1970. This surge in research interest started when biologists first successfully cultured giant clam larvae through to metamorphosis (e.g.
LaBarbera 1975; Jameson 1976). Numerous technical challenges had to be surmounted, including the unpredictability of spawning behaviour, unascertained dietary requirements in early life leading to high mortality rates, and difficulty in handling small metamorphosed juveniles (Yamaguchi 1977). There is now, however, a substantial body of data available on symbiosis and nutrition (e.g. Fitt and Trench 1981; Trench et al. 1981), reproduction (e.g. Gwyther and Munro 1981; Neo et al. 2011), shell morphology (e.g. Chan et al. 2009; Neo and Todd 2011a), and growth (e.g. Munro and Gwyther 1981; Guest et al. 2008). Field research has mainly concentrated on T. gigas, the largest and fastest growing species, and T. maxima, which has the most widespread distribution (Adams et al. 1988). Even though the biology, exploitation and mariculture of giant clams have been well-studied (reviews in Munro 1993; Lucas 1994; Hart et al. 1998), their ecology and behaviour are relatively poorly known.

One of the earliest articles on giant clams to contain behaviour-related information was published in 1865 (Vaillant 1865). It notes that these unique bivalves are not sessile and describes the relationship between shell weight and clam mobility as development progresses. Our search of the literature published between 1865 and 2013 yielded approximately 100 articles that included behavioural information. Nearly a third focus on spawning patterns and only a handful explore other behaviours quantitatively (e.g. Suzuki 1998; Huang et al. 2007). Brief qualitative or anecdotal notes (e.g. regarding larval studies in LaBarbera 1975; Jameson 1976; Fitt and Trench 1981) are much more common.

\section{Spawning}

Early research determined that tridacnines are functional protandric hermaphrodites that spawn sperm first and then eggs (Wada 1952, 1954). Such reproductive behaviour is not known to occur in other hermaphroditic bivalves (including the great majority of cockles), which generally discharge both sperm and eggs simultaneously. In general, male gonads mature at 2-3 years, whereas female gonads mature at 3-4 years (Lucas 1994). Larger species such as $T$. gigas, however, take longer to become functionally reproductive (e.g. 10 years) (Gomez et al. 2000).

Wada (1954) first described spawning in adults occurring in three distinct phases: the discharge of gametes from gonads, rhythmic contraction and relaxation of adductor muscles, and mantle movements (Lucas 1988; Husin et al. 2001; Tan and Yasin 2001b). Both sperm and egg spawning behaviours are similar (Wada 1954). Several rhythmical valve contractions are usually observed prior to either event, but the latent periods between sperm and egg release 
appear to show interspecies variation (Alcazar 1988). The simultaneous discharge of both sperm and eggs is abnormal, which Wada (1954) highlighted as indicative of an unhealthy adult. The fecundity of giant clams is exceptionally high (Yamaguchi 1977), even described as the 'pinnacle of fecundity in the animal kingdom' (Lucas 1994, $\mathrm{p}$. 187). The number of oocytes released per spawning adult (in the millions) is related to clam size (Alcazar and Solis 1986; Alcazar 1988; Husin et al. 2001). The period for fertilisation is limited by the short viability span of gametes, reported to be 4-6 h after release (Tan and Yasin 2001a). During ex situ fertilisation for mariculture, sperm and eggs are mixed typically within $15 \mathrm{~min}$ of egg release (Ellis 1998).

Reproductive seasonality and spawning cues

As with other cardiids (e.g. Galluccil and Galluccil 1982), giant clams display seasonal synchronous spawning within metapopulations (Heslinga et al. 1984; Shelley and Southgate 1988). Egg spawning of one individual will chemically trigger sperm spawning of nearby clams, thus ensuring gametes meet (Lucas 1988; Tan and Yasin 2001a). Adults are relatively sedentary, and given their reliance on external fertilisation, reproductive success is related to the density of the population (Adams et al. 1988; Downing et al. 1993). Individuals in close proximity tend to be more reproductively synchronised compared to those more spatially separated (Braley 1986).

Interspecific variation in reproductive seasonality is widespread in giant clams. The period for gamete maturation varies across species, but can be up to 4 months duration (Tan and Yasin 2001a). The majority of studies to date have been conducted over too brief a period for peaks in spawning intensity to be clearly defined (Munro and Heslinga 1983); however, some giant clams exhibit diel and lunar patterns, and seasonality is likely to be influenced by latitude and/or geographical locality (Braley 1984; Heslinga et al. 1990; Tan and Yasin 2001a) even at relatively small scales. For instance, populations of $T$. squamosa within the Tioman Archipelago, Malaysia, do not share the same spawning season (e.g. Pulau Tioman: SeptemberApril; Pulau Pemanggil: May-November) (Tan and Yasin 2001a).

Despite considerable research, no consensus has been reached on spawning frequency or natural mass spawning cues (Svane 1996). Temperature (Stephenson 1934) and water movement (Jameson 1976) have been suggested as stimuli for spontaneous spawning, but these have been dismissed by other researchers (e.g. LaBarbera 1975; Jameson 1976; Beckvar 1981). Compared to sperm release, observations of in situ egg spawning events are very rare even when gonads are 'ripe' (Braley 1984, 1986; Lucas 1994).
Specific environmental cues, such as phytoplankton blooms and temperature rises, may only occur in certain years and can account for sporadic egg spawning (Braley 1986; Tan and Yasin 1998). It is also possible that more than one cue is required to trigger synchronous spawning (Braley 1986); however, the potential synergistic effect of multiple environmental parameters are yet to be investigated (Tan and Yasin 1998).

Giant clams have been induced to spawn in laboratory conditions using cues such as macerated or freeze-dried gonads (Jameson 1976; Gwyther and Munro 1981), intragonadal injections of serotonin (Braley 1985; Crawford et al. 1986) and stripped eggs, either fresh or held overnight at $8{ }^{\circ} \mathrm{C}$ (LaBarbera 1975). The effectiveness of gonad suspension as a spawning stimulus is not only species-specific but also dependent on the sexual maturity, or ripeness, of the gametes (Wada 1954). Munro et al. (1983) postulated that the active cue is carried by the eggs and not the spermatozoa. The neurotransmitter serotonin can initiate spawning behaviour within five to ten minutes after injection into the gonads (Braley 1986; Husin et al. 2001). Braley (1986) mentioned thermal stress as a trigger for spawning in tank-held $T$. gigas and T. derasa but noted that the broodstock's physical and reproductive condition may be lowered.

\section{Locomotion}

Many benthic marine invertebrates possess complex life cycles characterised by planktonic larval phases followed by bottom-dwelling juvenile and adult stages (Thorson 1950; Watzin 1986). As larvae, dispersal by currents and searching for optimal settlement sites are key factors of early-life survival and therefore have significant effects at the individual, population as well as community levels (Rodríguez et al. 1993; Tan and Yasin 2001a). Starting with settlement and metamorphosis, locomotive activity declines with age, reflecting both anatomical constraints, in terms of byssus atrophy and shell weight-to-body mass ratio (Heslinga 1989), as well as ecological needs-where more energy is channelled into growth and reproduction.

Larvae

Within 7-16 $\mathrm{h}$ after fertilisation, the first larval stage to exhibit controlled movement is the ciliated gastrula (Table 1). LaBarbera (1974) and Jameson (1976) recorded active rotation within the water column by the gastrulae of numerous species, while those of H. hippopus remained on the bottom of the rearing tank (Fitt et al. 1984). Trochophores develop by $24 \mathrm{~h}$ post-fertilisation (Jameson 1976; Tan and Yasin 2001a) and are free-swimming and active 
Table 1 Locomotive behaviour exhibited by giant clam larvae

\begin{tabular}{llll}
\hline Developmental stage & Time after fertilisation & Locomotive behaviour & Species \\
\hline Ciliated gastrula & $7-16 \mathrm{~h}$ & Active rotation, remains at bottom & TC, TM, TS, HH \\
Trochophore & $12-24 \mathrm{~h}$ & Free-swimming, active at surface, translation & TC, TG, TM, TS, HH \\
Veliger & $18-72 \mathrm{~h}$ & parallel to and rotation around long axis & \\
Pediveliger & $4-19$ days & Active swimming throughout medium & TC, TG, TM, TS, HH, HP \\
\hline
\end{tabular}

$\mathrm{TC}=$ Tridacna crocea, $\mathrm{TG}=T$. gigas, $\mathrm{TM}=T$. maxima, $\mathrm{TS}=T$. squamosa, $\mathrm{HH}=$ Hippopus hippopus, $\mathrm{HP}=H$. porcellanus

(Fitt et al. 1984; Alcazar and Solis 1986). Cone-shaped $T$. squamosa trochophores have been observed swimming in a spiralling motion (LaBarbera 1974), and such locomotion may be facilitated by the presence of apical flagella on the anterior end (Raven 1966; Carriker 1990). Trochophore larvae do not orientate towards light (Fitt et al. 1984).

The transition to veliger is characterised by the development of the velum-which occupies approximately twothirds the volume of the shell cavity (Carriker 1990; Ellis 1998). Swimming is one of the functions of the velum (along with respiration and food collection), and it persists through to the pediveliger stage but degenerates subsequently (i.e. by juvenile stage). While the densely ciliated velum creates spiral swimming movements, the extension of the foot could possibly serve as a stabiliser (Fig. 1). The simultaneous use of the velum and foot has not been formally described but has been observed in T. squamosa (Mei Lin Neo, personal communication). Giant clam veligers have species-specific arrangements of the muscular system, which comprises of velar retractors for swimming and adductor muscles for valve closure (Bayne 1971a; Hickman and Gruffydd 1971; Jameson 1976).

The transition from the veliger to pediveliger stage is critical as it represents free-swimming larvae leaving the water column to metamorphose into benthic juveniles (Carriker 1990). In giant clams, pediveligers generally develop 6-14 days after fertilisation. Two anatomical features distinctive of this stage are a two-valved shell, and a ciliated foot with a sensitive propodial tip for crawling (Carriker 1990; Alcazar et al. 1987). The presence of a functionally active foot signifies larval competency for benthic locomotive activities and active exploration for suitable substrates (Purchon 1977).

The development of the posterior adductor muscles coincides with the time of visible pediveliger locomotion (Jameson 1976). Other structures that develop at this stage are the byssus complex and statocysts, and overall these changes give rise to a suite of behaviours observed during the pediveliger stage, including crawling, gliding, swimming, and substrate testing and orientation. Tridacna squamosa pediveligers were observed crawling 9 days after fertilisation by LaBarbera (1975). Crawling involves
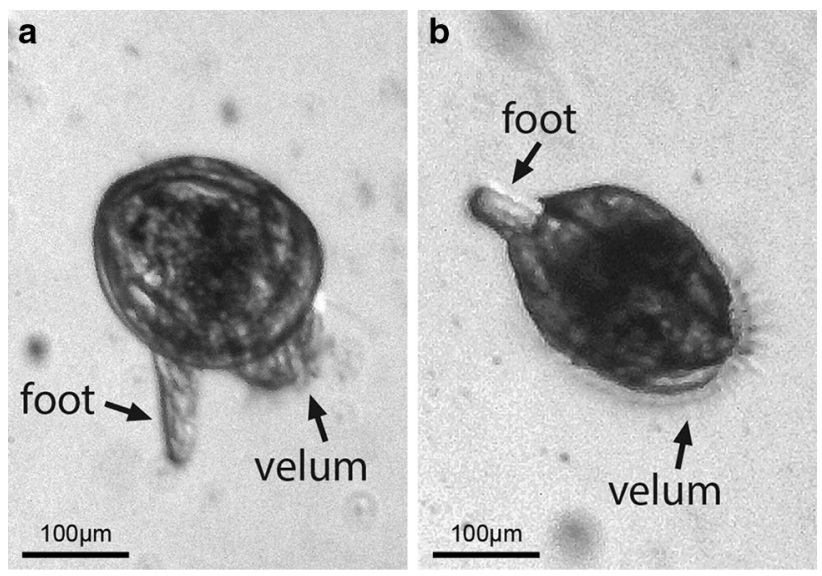

Fig. 1 Swimming in 8-day-old T. squamosa pediveligers: a a pediveliger just about to leave the substrate, $\mathbf{b}$ a pediveliger swimming using its velum - possibly using its foot as a stabiliser

anchoring the tip of the foot to the substrate, followed by the retraction of the pedal muscles to pull the body forwards (Jameson 1976). Gliding movement, i.e. a continuous 'pull', is created by the ciliated tip of the extended foot (Jameson 1976). This behaviour has been exhibited by the pediveligers of $T$. crocea, $T$. maxima and $H$. hippopus but not in $T$. squamosa, even though the surface of the foot in this species is ciliated (LaBarbera 1975).

\section{Substrate testing and orientation}

Giant clam pediveligers are believed to possess sensory and effector mechanisms within the foot similar to those in the blue mussel Mytilus edulis and giant scallop Placopecten magellanicus (Culliney 1974; Lane and Nott 1975). The foot is covered in cilia (at least for T. crocea, T. maxima, T. squamosa and $H$. hippopus) and likely functions as a sensory organ - testing the surrounding substrate and orienting the clam (Jameson 1976). Neo et al. (2009) reported that, in T. squamosa larvae, the tip of the extended foot moved in a sinoidal fashion and appeared to sense the substrate prior to crawling. Similar searching behaviour has also been observed in the bivalves Crassostrea virginica, Mercenaria mercenaria and Ostrea edulis (Yonge 1960; Cranfield 1973). 
Over time, the pediveliger becomes increasingly sedentary due to the increase in shell weight and reduction in velum size. The degeneration of the velum occurs simultaneously with the development of functional gills and usually confines the clam to the substrate it has chosen for settlement (Jameson 1976). In the case where suitable substrates are unavailable, the pediveliger stage may be extended, as in other bivalves such as Mytilus edulis and Placopecten magellanicus (Loosanoff and Davis 1963; Bayne 1965). Giant clam larvae tend to settle on substrates which offer shelter in the form of grooves and crevices, a behaviour frequently reported in corals (e.g. Petersen et al. 2005a, b). In aquaria, T. maxima larvae move towards, and byssally attach to, corners of tanks and the edges of plastic panels (Gwyther and Munro 1981). High substrate rugosity such as coral rubble and rough cement tiles also favours larval settlement (Alcazar and Solis 1986; Alcala et al. 1986; Neo et al. 2009). Calumpong et al. (2003) tested the settlement response of 13-day-old T. squamosa larvae on a variety of eight natural and artificial substrates: black pebbles, cement, coral rubble, dead coral, live coral, rough Mactan stone, smooth Mactan stone and Tridacna shells. Survival was consistently and significantly highest on rough and smooth Mactan stones, while shell growth was highest on cement.

Giant clam larval settlement can be elicited by chemicals associated with crustose coralline algae (CCA) (Courtois de Vicose 2000; Dumas et al. 2014). CCA is a well-established inducer of settlement and metamorphosis in many reef invertebrate larvae and, in an experiment to test its effect on giant clams, Neo et al. (2009) determined that significantly more $T$. squamosa larvae were attracted to small concrete tiles enriched with CCA covered coral rubble (CCACR) compared to control tiles. Pediveligers appear to be able to sense allelopathic compounds in scleractinian corals (e.g. review by Lang and Chornesky 1990) as they display anti-settling behaviour to live coral Porites spp. (Calumpong et al. 2003). Recently, Dumas et al. (2014) demonstrated that $T$. maxima larvae are also attracted to chemicals released into the water by juvenile conspecifics. Together, these results suggest a relatively well-developed chemosensory system in giant clam larvae.

\section{Juveniles}

It is often assumed that after settlement on a suitable substrate, giant clam pediveligers metamorphose into juveniles and lose the ability to move (Calumpong et al. 2003). This notion that juveniles are immobile and permanently attached to the substrate is not valid as they can continue to exhibit two types of movement: rotation and translation (Huang et al. 2007). Rotation is defined as a change of orientation without the approximate centre of the clam being shifted from its initial position, while translation refers to the lateral movement of the clam away from its original position. Huang et al. (2007, page 273) describes T. squamosa translation as the foot protruding out of the shell through the byssal orifice to contact the substrate for movement'. How much translation occurs can vary among species and substrates. For example, Toonen et al. (2012) grew four species ( $T$. squamosa, T. maxima, $T$. derasa and $T$. crocea) on 4-cm-diameter concrete 'plugs', but found that all of the T. squamosa had moved off these substrates by the end of their experiment. Rapid contraction of the valves also generates a force that supplements locomotion (Stasek 1962; Huang et al. 2007), but leaping of the type described in the cockles Laevicardium crassum and Cardium echinatum by Ansell (1967), where the foot is used to spring the animal up in the water, has not been recorded. Small individuals of $T$. crocea and $T$. squamosa (10-22 mm) are able to climb vertical surfaces with the aid of byssal threads (Yonge 1936; Huang et al. 2007).

Suzuki (1998) showed that $T$. crocea exhibited more locomotion at night, potentially an adaptation to reduce the risk of visual predation (Suzuki 1998). Soo and Todd (2012) examined the changes in locomotive activity under natural light conditions for T. squamosa. Eight individual juveniles were placed in the centre of separate tanks and filmed for $24 \mathrm{~h}$. Locomotion (facilitated by pedal locomotion and valve closure) occurred in four of the eight clams, and only at night. Three of the clams travelled more than $100 \mathrm{~mm}$. Vertical climbing was observed for a $17-\mathrm{mm}$ clam which crawled at least $70 \mathrm{~mm}$ up the tank wall in the night and remained there during the daytime. This nocturnal activity appears to be more pronounced in giant clams than in other cardioids such as Cerastoderma edule (Richardson et al. 1993).

Existing knowledge of the tactic response of giant clams to directional abiotic stimuli (i.e. light, chemicals, and gravity) is limited to juveniles. Given the tendency for photosynthetic zooxanthellae to move towards illuminated sources (Hollingsworth et al. 2005) and induce a similar response movement in hosts such as coral planula and sea anemones (Atoda 1953; Zahl and McLaughlin 1959), giant clams might also be expected to be phototactic. However, Huang et al. (2007) rejected the hypothesis that T. squamosa juveniles move towards light as they found no significant relationship between direction of light source and direction of movement under experimental conditions.

Even though chemical attraction is one of the more challenging biological phenomena to quantify, Huang et al. (2007) demonstrated positive chemotaxis in giant clam juveniles. In a choice experiment using bidirectional water inflow, T. squamosa juveniles moved towards the effluent of conspecifics as opposed to clean seawater. Similar results have been found for T. maxima juveniles (Dumas 


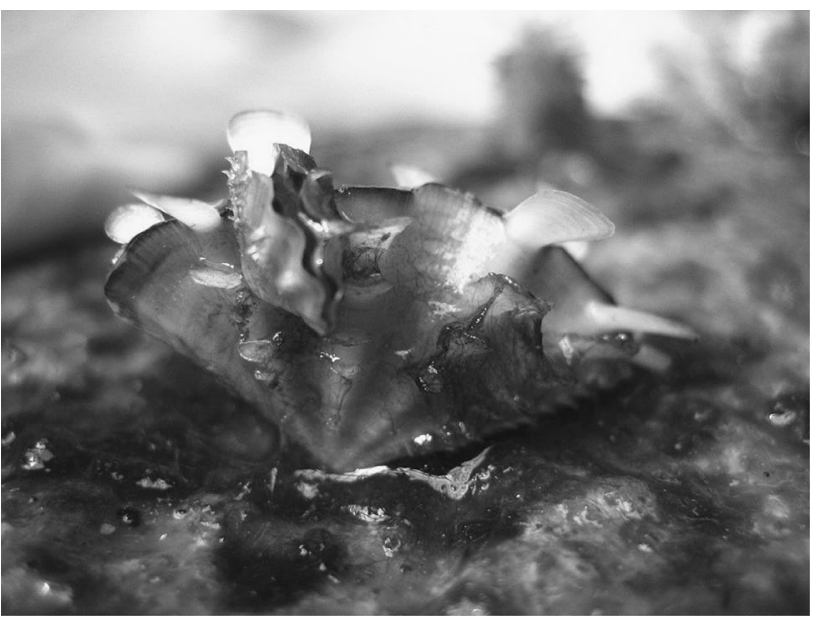

Fig. 2 An example of a smaller T. squamosa juvenile $(8.5 \mathrm{~mm})$ attached to the valve of a larger $T$. squamosa individual $(27.8 \mathrm{~mm})$, possibly due to overcrowded conditions

et al. 2014). Huang et al. (2007) suggested chemical signalling was a proximate mechanism for non-random aggregation (i.e. clumping), the benefits of which they suggested to be: lower individual risk of predation (e.g. Reimer and Tedengren 1997; Krause and Ruxton 2002), high reproductive success during mass spawning (Adams et al. 1988; Downing et al. 1993) and physical stabilisation against abiotic stresses (Seed 1969; Bertness and Grosholz 1985). By moving non-randomly towards conspecifics while they are small in size, juveniles can form clumps before shell growth and weight become limiting factors to locomotion. A potential negative outcome of clumping is overcrowding and may explain why sometimes smaller individuals climb and attach to the valve surfaces of larger conspecifics (Fig. 2).

When testing for clumping in juvenile T. squamosa, Huang et al. (2007) only recorded positions at the beginning of their experiment and then again at its end (i.e. after 3 days). To gain a better understanding of the locomotive behaviour involved, Soo and Todd (2012) used time-lapse photography to track the aggregation process in $63 \mathrm{~T}$. squamosa juveniles. The clams clumped within $24 \mathrm{~h}$ (Fig. 3) with mean distance travelled estimated at $280 \mathrm{~mm}( \pm \mathrm{SE}$ 34.9). Locomotion away from the initial position was observed in $81 \%$ of the clams, and, in concurrence with the studies on day-night locomotive activity (see above), this was limited to night time (between $8.30 \mathrm{pm}$ and 5.00 am).

Juvenile $T$. crocea and $T$. squamosa frequently climb the vertical surfaces of experimental tanks (Yonge 1936; Huang et al. 2007; Soo and Todd 2012), and Jameson (1976) considered this behaviour to be anti-predatory. Casual observations of $T$. squamosa vertically climbing when
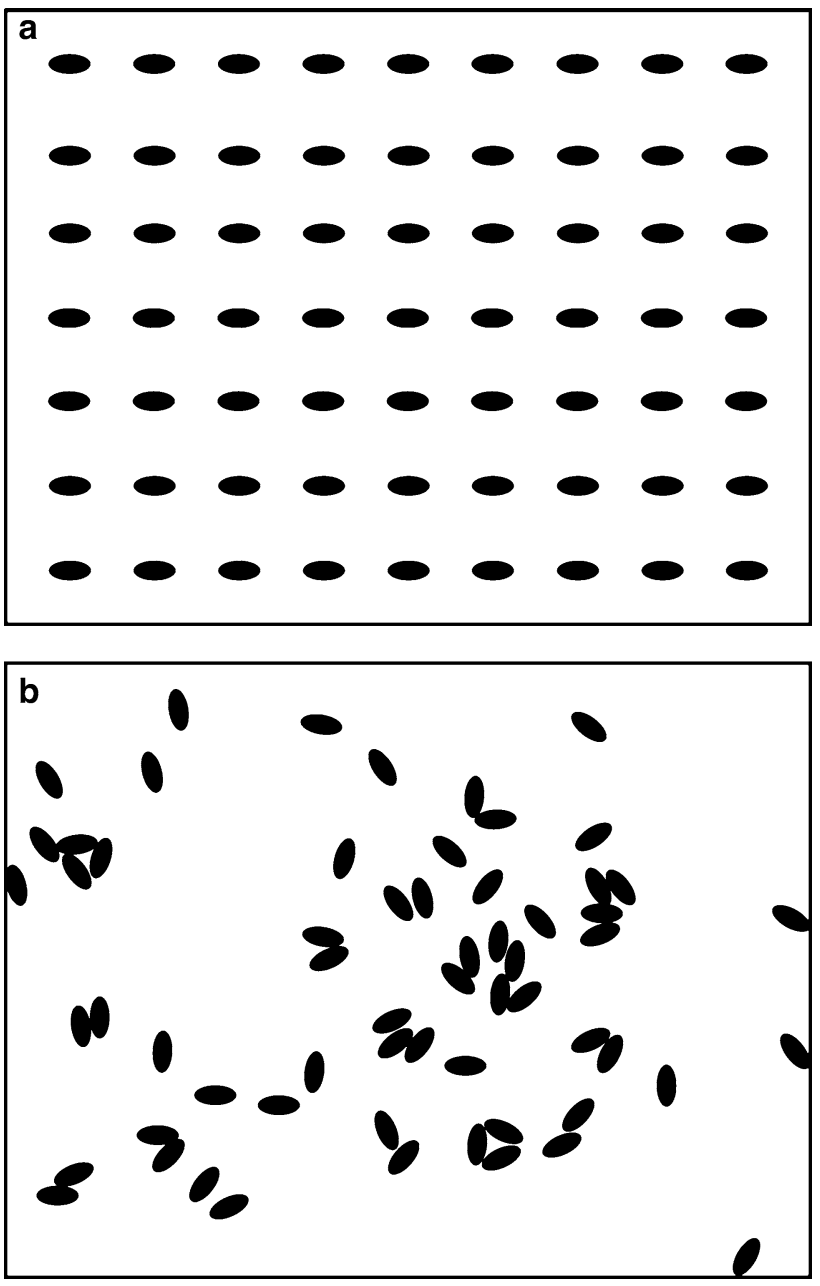

Fig. 3 Positions of T. squamosa juveniles at the a start of the aggregation experiment and $\mathbf{b}$ after $24 \mathrm{~h}$. Image is based on the video stills in Soo and Todd (2012)

exposed to predator effluent (as compared to no-effluent controls) were made by Neo and Todd (2011a), seem to support Jameson's (1976) hypothesis. However, Soo and Todd (2012) identified geotaxis in the opposite direction in juvenile T. squamosa when they showed that significantly more clams ( 10 out of 16$)$ moved down concrete tiles tilted at a $60^{\circ}$ angle than up them. The coral reef is a spatially complex habitat which can provide refuge and settlement areas for many benthic invertebrate taxa (Idjadi and Edmunds 2006); therefore, the ability to move over, climb and descend within this environment is probably highly adaptive.

Adults

Locomotion (displacement of $\sim 20 \mathrm{~cm}$ in 3 days) in a 313mm shell length $T$. squamosa was observed by Huang et al. (2007), and adults are generally able to right themselves 
Table 2 Ontological changes in acquiring nutrition

\begin{tabular}{|c|c|c|c|}
\hline Developmental stage & Diet & Start (duration) & Source/mode of acquiring nutrition \\
\hline Larva & $\begin{array}{l}\text { Lecithotrophic } \\
\text { Planktotrophic }\end{array}$ & $\begin{array}{l}\text { Embryo (unknown) } \\
\text { Veliger stage }\end{array}$ & $\begin{array}{l}\text { Egg yolk reserves (Fitt et al. 1984) } \\
\text { Velum is used for feeding (Carriker 1990) }\end{array}$ \\
\hline Pediveligers & Particulate & $\begin{array}{l}\text { After metamorphosis } \\
(\sim 1 \text { week) }\end{array}$ & $\begin{array}{l}\text { Pedal feeding (Reid et al. 1992): } \\
\text { 1. Locomotory pedal feeding } \\
\text { 2. Pedal sweep-feeding } \\
\text { 3. Pedal probe-feeding }\end{array}$ \\
\hline Juvenile, Adult & $\begin{array}{l}\text { Heterotrophic } \\
\text { Phototrophic }\end{array}$ & $\begin{array}{l}\text { Maturation of ctenidia } \\
\text { Establishment of symbiosis }\end{array}$ & $\begin{array}{l}\text { Filter feeding (e.g. Yonge 1936) } \\
\text { Photosynthates from symbiotic zooxanthellae } \\
\quad \text { (Streamer et al. 1988) }\end{array}$ \\
\hline
\end{tabular}

(Fankboner 1971). Studies on tactic responses in mature giant clams are absent.

\section{Feeding}

Fankboner and Reid (1990) noted that tridacnines are not only the largest bivalve to have lived, but also possibly the most opportunistic. Their unique repertoire of feeding modes allows them to adapt to changes in local environment factors (Reid et al. 1984). Starting with a lecithotrophic and planktotrophic diet during larval stages, giant clams then switch to pedal feeding after metamorphosis and this is followed by the transition to a dual mode of filter feeding and phototrophy upon establishing symbiosis with zooxanthellae (Table 2). The reorganisation of feeding at metamorphosis is likely one of the most extreme within the catalogue of giant clam behaviours and probably accounts for the high mortality rates observed during the transition from trochophore to veliger and from pediveliger to juvenile (Fitt et al. 1984).

\section{Larvae}

The ability to feed is absent in the early stages of giant clam larval development as they initially rely on nutrients stored in the egg yolk (Heslinga et al. 1990). The formation of a functional filter-feeding apparatus (velum) at the veliger stage suggests a switch to exogenous sources. Within 2-3 days after fertilisation, veligers develop hollow intestines and are demonstrable planktotrophs. They actively uptake flagellates ( $\sim \mu$ m diameter), zooxanthellae and dissolved organic nutrients from the seawater via the mouth (Fitt et al. 1984; Braley 1986; Alcazar et al. 1987). The food is kept in motion by stomach cilia (Jameson 1976).

While growth rates during early life are greatest in veligers, mortality plagues the trochophore-veliger transition (Fitt et al. 1984). Braley (1986) recommended targeting the change from lecithotrophic to planktotrophic feeding to reduce larval death in aquaria. The provision of a mixed micro-algal diet with high lipid composition and fat-soluble nutrients within this time frame is believed to increase the chances of surviving the transition from trochophore to veliger (Fitt et al. 1984; Neo et al. 2013a). Compared with adult clams, symbiotic zooxanthellae are not a major source of nutrition during the larval stages (Fitt et al. 1984). Veliger larvae of T. gigas and H. hippopus can metamorphose into juveniles in the absence of symbiotic algae and phytoplanktonic food (Gwyther and Munro 1981). An externally introduced food supply, however, appears to increase veliger growth rates as well as shorten the time to metamorphosis (Fitt et al. 1984).

Pedal feeding generally refers to using the foot as a feeding organ to collect food particles on the substrate surface, and this can sustain pediveligers and young juveniles until the inhalant siphon and ctenidial food grooves are functional for filter feeding (Reid and King 1988). Tridacna gigas juveniles (and probably those of all giant clam species) possess the behavioural and neurophysiological capacity for three putative forms of pedal feeding (Reid et al. 1992). Forward locomotion over a hard substrate creates an anterior current flow through the pedal gape, allowing small clumps of detritus on the substrate surface to enter the mantle cavity. The second form is anteroposterior pedal sweepfeeding on a sandy substrate, during which the foot extends posteriorly and is swept forward with slight rotation before retracting. Mucus strings produced by the foot traps sediments which are then ingested. Thirdly, while in an upright position, probing of the foot down into the substratum may enable the pedal cilia to gather particulate food. It has yet to be determined how important pedal feeding is during the metamorphosis-ctenidial maturation time gap. The difficulty in quantifying the nutritional significance of this feeding mode is compounded by the establishment of endosymbiotic zooxanthellae during the same period.

Giant clams derive a substantial portion of their food from their symbiotic dinoflagellate algal symbionts (Symbiodinium) harboured in their hypertrophied mantle tissues (Lucas, 1994). Species can host multiple clades, for 
instance DeBoer et al. (2012) found 11 Symbiodinium types belonging to clades A, C, and D in T. crocea (more clams with $\mathrm{C}$, less with $\mathrm{D}$ ), $T$. squamosa (more clams with $\mathrm{D}$, less with $\mathrm{C}$ ) and $T$. maxima (no clear pattern) in Indonesia. They also found that $42 \%$ of the clams sampled simultaneously hosted more than one clade (DeBoer et al. 2012). Research on the early development of giant clams (e.g. LaBarbera 1974) concluded that zooxanthellae are not inherited by the offspring but rather that each generation of giant clams is independently infected with algal symbionts (Stephenson 1934; LaBarbera 1975; Jameson 1976). Hence, larval or juvenile clams must actively acquire zooxanthellae from the environment through feeding. Symbiosis was thought to be only established fully only after metamorphosis (Fitt and Trench 1981; Fitt et al. 1984), when tubules extend from the digestive gland into the developing siphonal tissues. More recently, however, Mies et al. (2012) found greater growth and survival rates in larvae with zooxanthellae, suggesting that the larvae are gaining some benefit from the association at this early stage.

As with the Cardiidae in general, giant clams are opportunistic filter feeders (Yonge 1936; Malham et al. 2012). Details of their ciliary feeding mechanism have been described by Purchon (1955a, 1977) and Morton (1967). The transition from pedal feeding to filter feeding can only take place when the ctenidia has reflexed and formed food grooves (Yonge 1974; Reid et al. 1992). When giant clams filter feed, the valves gape widely and mantle lobes become fully exposed (Wada 1954). Large volumes of seawater, containing planktonic larvae, zooxanthellae, protozoans and particulate matter in mucus flocs released by corals, are pumped through the mantle cavity-especially during daytime (Yonge 1936). The ciliary tracts on the gill remove this material, and water is passed back out through the exhalant siphon (Hardy and Hardy 1969). Giant clams are efficient utilisers of particulate organic matter, retaining on average three quarters of particles $2-50 \mu \mathrm{m}$ in size. Under turbid water conditions and corresponding reduced light intensity, $T$. squamosa are able to increase filter-feeding rates (Tedengren et al. 2000), a behaviour not observed in other giant clam species (Klumpp and Lucas 1994).

Juveniles and adults

Both late juveniles and adults share the same feeding behaviours. They obtain nourishment in four ways: (1) autotrophic feeding via the transfer of photosynthates produced by zooxanthellae in the mantle tissues, (2) digestion of zooxanthellae, (3) filter-feeding and (4) uptake of dissolved organic and inorganic molecules (see reviews in Fankboner and Reid 1990; Fitt 1993; Lucas 1994). Three behaviours related to valve movements, waste removal, behaviour during emersion and circadian rhythm, are highlighted below. They are intrinsically linked to both autotrophic feeding and filter feeding, as the efficiency of the former relies on light capture while the latter depends on the rate of water current flowing through the siphons.

Periodically, bivalves rapidly clap their shell valves to expel waste such as foreign matter or pseudofaeces that have entered the infra-branchial cavity. During this process, water can escape from the proximal oral grooves into the infra-branchial cavity and therefore flush out the mucous food cords. Various adaptations to enclose the proximal oral grooves and protect the food train from dislodgement by such violent water movements have been adopted by numerous monomyarian bivalve species, including Ostrea edulis and Pecten maximus (Gilmour 1964). Interestingly, these structures remain unspecialised in Tridacna spp. (Purchon 1977).

Undisturbed giant clams typically have valves that gape open (Yonge 1936; Hickman and Gruffydd 1971; MingoaLicuanan and Lucas 1995) and even when intertidal species such as T. crocea and T. squamosa are exposed by low tides, they continue to display valve gaping (Rosewater 1965; Wilkens 1984; Mingoa-Licuanan and Lucas 1995). Gaping behaviour during emersion is indicative of both active ventilation, as shown in mussels (Bayne 1971b), and aerial photosynthesis - even though the mantle tissues are withdrawn (Lucas et al. 1989). Physiological studies on the effects of emersion on giant clam nutrition have demonstrated that they can photosynthesise out of water (Mingoa-Licuanan and Lucas 1995) and aerial phototrophy in $T$. gigas juveniles is estimated to satisfy more than $100 \%$ of the carbon requirements for metabolism. Thus, the ability of giant clams to maintain energy input through zooxanthellar photosynthesis distinguishes them from other nonphotosynthesising intertidal bivalves which also gape when exposed by low tides.

The feeding behaviour in giant clams has a marked circadian rhythm (Fankboner 1971; Morton 1978; Reid et al. 1984; Fankboner and Reid 1990); solar and lunar cycles which determine food availability in turn influence the diurnal feeding activity. At night, they withdraw their mantles and close their valves either half-way or fully, remaining quiescent till dawn (Gwyther and Munro 1981; Heslinga et al. 1984). During this period, weak siphonal activity indicates little respiratory exchange. There is also a lack of response to light, and tactile stimulation elicits only small, sluggish valve adduction (Stasek 1965; Fankboner 1981). 1-3 $\mathrm{h}$ prior to sunrise, the response to shadows, water turbulence and tactile stimuli is typical of those during full daylight, i.e. rapid, multiple adductions with expulsions of large volumes of water (Fankboner and Reid 1990). 


\section{Anti-predator behaviour}

Natural predators of giant clams vary in their attack mode according to the age or size class of their prey. Young clams are highly vulnerable to crabs (e.g. Thalamita spp., Demania spp.) that use their chelae to crush the shell valves; wrasses (Halichoeres spp.) feed on the byssus and foot of unanchored clams; and pyramidellid and ranellid snails are parasitic (Alcazar 1986). Tooth marks on the outer shell surfaces are indicative of attacks by grazing reef fish (Stasek 1965). For older clams, potential predators include eagle rays, turtles and large benthivorous fish (Bustard 1972; Govan et al. 1993), but their impact is reduced as the clams grow towards escape size (Adams et al. 1988).

Constitutive anti-predatory defences present in giant clams include camouflaging mantle colours and polymorphism (Todd et al. 2009) thick and heavy shells (Lin et al. 2006; Neo and Todd 2011a) and, in some species, sharp shell projections called 'scutes' (Ling et al. 2008; Chan et al. 2009). Behavioural defence mechanisms revolve primarily around the closing of valves, mediated by the contraction of adductor muscles (Morton 1967). This shell-closing reaction has been observed at all developmental stages. Mechanical disturbances within a clam's immediate environment may be interpreted as predatory attacks and elicit various degrees of valve closure, such as rapid muscular adductions or an extended period of remaining shut. The water residing in the mantle cavity is expelled either through the inhalant aperture or exhalant siphon as a jet (Morton 1967). Depending on the strength of the muscular contraction, the valve closure response can function defensively in at least three ways: (1) by reducing the amount of soft tissue exposed and thus vulnerable to attack, (2) by providing locomotion and escape during larval and juvenile stages (e.g. Ansell 1967; Jameson 1976; Huang et al. 2007) and 3) by producing jets of water that can startle fish (Stasek 1965).

\section{Larvae}

When disturbed, giant clam veligers display a fright reaction, i.e. withdrawal of the velum into the shell, closure of valves and passive sinking (LaBarbera 1974), and this represents the only defence mechanism known at this lifestage. It can be observed within $38 \mathrm{~h}$ of fertilisation, usually at least $2 \mathrm{~h}$ after the calcification of shell rim and the full formation of the retractor and adductor muscles. During subsequent larval stages, the pattern of calcification appears to rapidly reinforce those areas which are necessary to effect the fright reaction and which are subjected to the greatest stress during valve closure. The speed and coordination involved in valve closure may reflect the neuronal innervations of these muscles and their ability to respond to mechanical stimulation (Marois and Carew 1990).
Juveniles

Giant clams exhibit two forms of visually mediated behaviours: shadow response and 'sight reaction' (Stasek 1965; McMichael 1974). The former is characterised by a withdrawal reflex common among bivalves experiencing passing shadows (Land 1968), while the latter also involves mantle withdrawal but this time in response to moving objects even when their shadows do not fall directly on the clam. Several authors have reported dependence on a visual system during daylight hours to avoid attack by reef fish and other predators (Stasek 1965; Wilkens 1986). Giant clam pin-hole eyes can be found along the mantle margins and Land (2003) noted several hundred in T. maxima juveniles (150 mm shell length). They constitute a mass of retinal cells devoid of a lens, but the cooperative functioning of small numbers of siphonal eyes could confer directional sensitivity (Fankboner 1981).

During daytime, shadows with abrupt changes in intensity or movement elicit rapid retractions of the mantle coupled with valve adduction, producing a spout of water from the exhalant siphon (Wilkens 1986). This behaviour is thought to be centrally coordinated and serves to startle potential predators via movement of the colourful mantle coupled with the squirting of water (Wilkens 1981). Tridacna maxima and T. squamosa are more sensitive to shadows and tactile stimuli than T. gigas (Fankboner 1981). Reduced valve adduction in response to repetitive visual stimuli suggests habituation (Fankboner 1981). Compared to visual cues, mechanical and tactile stimuli trigger faster mantle and shell movements (Wilkens 1986). The valve adduction of a $450 \mathrm{~mm} T$. derasa following a mechanical stimulus was more rapid $\left(0.37 \mathrm{~m} \mathrm{~s}^{-1}\right)$ than for a shadow response $\left(0.28 \mathrm{~m} \mathrm{~s}^{-1}\right)$.

While filming the behaviour of juvenile T. squamosa in the presence of cardboard fish models, Neo (2009) noted both oscillatory and unidirectional squirt patterns and reported an ability to hit these models regardless of their position (i.e. in line with longitudinal axis of the clam, or at $45^{\circ}$ to this axis). This suggests that 'aiming' with the exhalant siphon, as described in adult T. maxima adults (Stasek 1965), also occurs in juvenile clams. Neo and Todd (2011b) analysed stills from video recordings of squirting juvenile T. squamosa (for an example see Fig. 4) to calculate the initial velocity, force and pressure exerted by each squirt on an object. They found positive correlations between shell length and the force exerted, but that the pressure produced decreased rapidly with distance from the clam.

\section{Adults}

SCUBA divers often observe that giant clams are able to sense their presence and respond to shadows by closing 


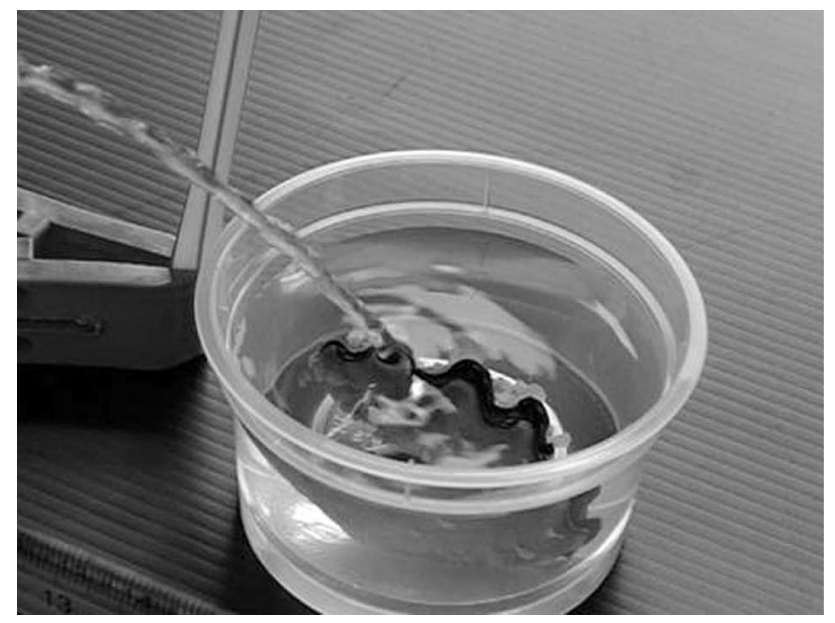

Fig. 4 A juvenile T. squamosa squirting a jet of water from its exhalant siphon

their valves to varying degrees (Rosewater 1966; Hickman and Gruffydd 1971; Morton 1978). Adults possess numerous ( $>3,000$ for a $900 \mathrm{~mm} \mathrm{~T}$. gigas) pinhole eyes along their mantle margins, constituting the visual mechanism to mediate defensive withdrawal responses (Fankboner 1981). The initial response of T. maxima adults to shadows is the overlapping and infolding of the lips of the exhalant cone. Larger species exhibit mantle withdrawal only, while smaller species close their valves in the presence of passing shadows. Flickering shadows cast by small surface waves have no effect. Stasek $(1962,1965)$ concluded that the shadow reaction is an adaptation to the presence of reef fish such as parrotfish and surgeonfish that gnaw and scrape the coral substratum. Based on in situ observations of adult clams in the presence of roving reef fish, Stasek (1965) described giant clams as being able to perceive moving objects. Even though shadows of the fish did not fall on the clam, the presence of small pomacentrids caused partial and temporary retraction of mantle lobes while larger fish elicited incomplete valve closure.

Giant clams at rest have valves that invariably gape open to maximise light capture by the hypertrophied mantle tissues which house millions of photosynthetic zooxanthellae (Yonge 1936; Hickman and Gruffydd 1971). Stasek (1965) observed no visible response to hammering, scratching on coral or fluttering hand movements below the lateral mantle expansions. Vibrations travelling through the water were thus not the stimulus necessary to elicit mantle retractions typical of shadow responses. However, direct mechanical stimulation of the mantle can elicit valve adduction in adult giant clams, often generating a forceful jet of seawater from the exhalant siphon (McMichael 1974; Morton 1978). Numerous observations of such squirting reflexes have been reported by SCUBA divers and scientists; for example, McMichael (1974, p. 254) noted that it was 'an occupational hazard when measuring clams to be regularly squirted in the face'.

Stasek (1965) concluded that the aiming-spurting behaviour which he observed in T. maxima adults is not of unique adaptative significance. He argued that, while the jet of water produced by valve adduction is sufficiently strong to drive away small fish, it is likely only enough to induce a temporary startle reaction in larger fish. Even so, startling may provide enough time for the clam to retract its exposed mantle lobes into its shell (Wilkens 1984). While it is clear that squirting is a common outcome of the rapid adduction of valves, its function as an anti-predatory behaviour in situ has yet to be fully tested.

\section{Stress responses}

Marine bivalves, including cockles, are known to be susceptible to contaminants and other stressors (Malham et al. 2012). The effects of environmental and anthropogenic factors on giant clams are not well-established, although the ability to sense and respond to such impacts undoubtedly influences their survival (Elfwing et al. 2001). Only a handful of papers have studied giant clam responses to stress (e.g. Svane 1996); these include sediment and sand loading, physical dislodgement, exposure to heavy metals, reduced salinity, and elevated temperatures.

\section{Larvae}

Even though larval stages of invertebrates are generally sensitive to environmental changes, research on stress responses during early giant clam development is very limited. Blidberg (2004) demonstrated that decreased salinity and exposure to low doses of copper are synergistic stress factors for T. gigas larvae. Greater numbers of swimming veligers suggested an inhibition or delay in metamorphosis, similar to other invertebrates exposed to heavy metal contaminants (e.g. Lyons et al. 2002). The extension of the pelagic larval stage may act as a biological cue for toxicity and explain the anti-settling behaviour of giant clam larvae near populated coastal areas and river mouths (Blidberg 2004). Neo et al. (2013a) tested the effects of temperature ( 22.5 vs. $\sim 29.5^{\circ} \mathrm{C}$ ) and salinity ( 27 vs. $30 \%$ ) in T. squamosa. They determined that fertilisation success was significantly greater at the higher temperature, but resulted in almost total mortality at $24 \mathrm{~h}$. They found no significant differences in either embryo or trochophore numbers between the two salinities. A subsequent study by Eckman et al. (2014) noted that T. squamosa trochophores exposed to salinities of $9 \%$ (up to $3 \mathrm{~h}$ ) and veligers exposed to salinities of $12 \%$ (up to $42 \mathrm{~h}$ ) stopped swimming and sank to 
the bottom of the test containers. However, when returned to fresh seawater, they resumed their normal swimming activity within an hour. In the same study, late-stage pediveligers or early-stage juveniles (2.3-3.0 mm shell length) responded to zero-salinity distilled water by withdrawing their mantle tissues and siphons and closing their valves. After up to $5 \mathrm{~h}$ under these conditions, all specimens recovered within $30 \mathrm{~min}$ of being returned to seawater (Eckman et al. 2014).

\section{Juveniles}

Living in association with shallow-water coral reefs, giant clams are often subjected to wave action and wave-induced re-suspension of sediments (Lund-Hansen et al. 1999). Purchon (1955b) was one of the first authors to note that entry of sand and sediments into the mantle cavity of bivalves through the siphonal apertures could potentially cause organ damage. If the guard tentacles at the inhalant aperture fail to stop such unwanted materials, it can be removed from the mantle cavity by ciliated waste canals or by jets of water ejected through the exhalant siphon. Elfwing et al. (2001) identified three behavioural responses of $T$. squamosa juveniles placed in sediment-loaded waters: partial contraction of mantle, full contraction of mantle, and mantle cavity exhalation. The intensity of behavioural activity recorded for sediment treated clams was significantly higher than for control clams. Elfwing et al. (2001) also demonstrated that previous exposure to copper increased the activity of clams then exposed to sediments. To further quantify the behavioural responses to sand deposition in juveniles, we individually exposed $16 \mathrm{~T}$. squamosa clams (26-71 mm) to 1-g reef sand deposited from a height of $\sim 50 \mathrm{~mm}$. The responses of the clams were videoed for $1 \mathrm{~h}$. The juveniles removed sand by mantle contractions and ejecting water. The behavioural responses to sand loading were similar to the three described by Elfwing et al. (2001), except that we also observed water being ejected through the inhalant siphon, not just the exhalant. Qualitatively, the clams appeared to be able to remove most of the sand within the hour of video recording. The behavioural responses to silt (Elfwing et al. 2001) and sand (present study) suggest a certain level of resilience to the physical effects of sediment stress.

Righting is a critical biological function in molluscs (e.g. Peck et al. 2004). A common behaviour in bivalves, it involves the active re-alignment to a vertical position after physical displacement (Waller et al. 1999). Giant clams gain a substantial portion of their energy from phototrophy, and an upright posture favours maximum light capture. Filter feeding and locomotion are also best achieved when upright. Without byssus for anchorage to the substrate, free-living species such as $T$. gigas and $H$. hippopus have a higher predisposition to be toppled by wave action or swimming predators (Fankboner 1971). To observe righting behaviour in juvenile $T$. squamosa, we used a wooden rod to repeatedly topple 14 individuals $(14-54 \mathrm{~mm}$ in shell length). We noted two methods of righting behaviour, each only taking a matter of seconds. Smaller individuals (up to $30 \mathrm{~mm}$ ) tended to use the foot as an anchor (the foot was seen to repeatedly extend then retract through the pedal gape before attaching to the substrate) and valve adduction to jerk upright. In contrast, larger juveniles $(>30 \mathrm{~mm})$ relied on rapid and forceful valve adduction to return to an upright position. This method used a strong jet of water expelled through the exhalant siphon to create a 'push' force for righting.

Ecotoxicological research has focused mainly on juveniles (e.g. Blidberg et al. 1999; Elfwing et al. 2002, 2003). Sub-lethal exposure to copper $\left(50 \mu \mathrm{g} \mathrm{l}^{-1}\right)$ and low salinity (20 psu) can significantly lower the ratio between gross photosynthetic production $\left(P_{\mathrm{g}}\right)$ and respiration $(R)$ values (Elfwing et al. 2001). Copper concentrations much higher than $50 \mu \mathrm{g} \mathrm{l}^{-1}$ have been reported in reef waters (review by Peters et al. 1997). Sub-bleaching temperature levels can affect photosynthetic performance, reducing the energy available for growth and reproduction (Blidberg et al. 2000). When ambient temperature is raised by three degrees over $24 \mathrm{~h}, T$. gigas and T. derasa juveniles display negative trends in net oxygen production and respiration rates but higher $P_{\mathrm{g}}: R$ ratios due to decreased respiration (Blidberg et al. 2000). There is also a difference in sensitivity to heat stress, with photosynthetic efficiency decreasing most in T. derasa and metabolic demand increasing most in H. hippopus (Blidberg et al. 2000).

Adults

Within the literature on giant clam adults, there are fragments of information regarding the effects of physical displacement and high temperatures. Only Fankboner (1971) has attempted to explain righting behaviour in adults in relation to shell morphology. While byssate species such as T. squamosa and T. crocea are able to anchor onto the substrate (Yonge 1936), free-living species may be toppled by strong waves during storm conditions, or roll laterally for a short distance across the reef (Purchon 1977). Yet, they are rarely seen in any position other than upright (Fankboner 1971). In addition, the lack of size stratification with depth suggests that $T$. derasa adults are not adversely affected by wave-induced turbulence (Adams et al. 1988).

So far, two hypotheses have been proposed for how giant clams regain their original position: an 'automatic righting system' (Purchon 1977) and a step-wise, self-righting response (Fankboner 1971). Purchon (1977) noted that heavy deposits of nacre occur within the umbonal region. 
This thickening enhances postural stability by lowering the clams' centre of gravity, hence the 'automatic righting system'. Regardless of how the shell is rocked and rolled over by the waves, it will always come to rest with the umbones lowermost given their substantial mass (Hickman and Gruffydd 1971). Fankboner (1971) contested this idea with his observations that clams go through a righting response after toppling. While not ruling out Purchon's theory of righting as an inherent benefit from modified shell morphology, he noticed that toppled clams in the field (Eniwetok Atoll, Marshall Islands) do not automatically right themselves. Instead, T. gigas and H. hippopus adults both engaged in a stepwise sequence leading to righting. When toppled over by wave action, the valves remain closed for a period of time, between 1 and $72 \mathrm{~h}$, after which the adductor muscle relaxes and the hinge ligaments spring the valves apart. The displacement of the uppermost heavy umbone to one side acts as a counterweight for self-righting (Fankboner and Reid 1990).

For zooxanthellate reef organisms such as corals, an increase in seawater temperature by a few degrees above the seasonal maximum is likely to induce the dissociation of symbionts (Glynn 1993). This process of bleaching has been recorded several times in giant clams and manifests in the expulsion of Symbiodinium, resulting in the loss of colour from mantle tissues (Braley 1986; Gomez and Mingoa-Licuanan 1998; Gomez et al. 2000). Mantle withdrawal beyond the edges of the valves is also common and over prolonged periods of thermal stress precedes death. In some cases, small bubbles form under the epidermal layer of the mantle of a heat-stressed clam, but recovery has been observed within 1 month (Braley 1986). The ability of giant clams to host multiple Symbiodinium clades, including clade D that is known to be thermally tolerant (Stat and Gates 2011), may confer some resistance to thermal stress anomalies.

\section{Why understanding giant clam behaviour is important for their conservation}

Giant clam populations throughout their range are disappearing at an alarming rate due to anthropogenic impacts such as overexploitation for food and the aquarium trade, pollution, and habitat loss. Once clam density reaches a point where it becomes unlikely that the gametes of these broadcast spawners can meet and fertilise (the component Allee effect), the ability for a population to self-sustain is compromised (Neo and Todd 2012b). Under such conditions, one of the few conservation options is to intervene and restock to raise densities to levels that increase the probability of natural recruitment. Mariculture of giant clams can produce large numbers of individuals suitable for restocking corals reefs and has contributed to a number of successful restoration efforts (e.g. Soloman Islands, Bell 1999; Philippines, Gomez et al. 2000).

The first step in mariculture is to produce gametes for fertilisation, and intragonadal injection of serotonin has proven to be most effective method in stimulating individuals to release sperm and eggs; however, it also causes some stress to the clams. Even though the exact cues for spawning in the wild have yet to be elucidated, giant clams display diel and lunar periodicities in reproduction and general peak breeding seasons have been established for some species. Induced spawning should therefore be planned around these time frames to take full advantage of their natural reproductive cycles (Ellis 1998). Existing conflicts in short-term monitoring spawning data could be resolved with long-term in situ monitoring of spawning behaviour and fecundity (e.g. Fujikura et al. 2007). Future work could also test for plasticity in spawning - to examine whether it is possible to advance or delay gamete maturation in order to exploit optimal spawning conditions (Tan and Yasin 1998).

Despite the substantial body of research into rearing techniques, ex situ cultured giant clams generally experience high mortality during metamorphosis and growth (e.g. Jameson 1976; Fitt et al. 1984; Ellis 1998). For example, complex switches in the mode of acquiring nutrition as larvae develop into juveniles were highlighted in the section on feeding behaviour. Unsuitable feeding regimes, for pedal feeding at larval stages in particular, are a probable cause for high post-metamorphic mortality rates (Reid et al. 1992). It is essential to provide early pedal-feeding larvae an environment comprising physical properties matching this mode of feeding, especially in terms of substrate rugosity and the size of food particles (Reid and King 1988). Determining species-specific timelines for changing modes of nutrition should similarly be a research priority.

Locomotion in giant clams also has implications for mariculture and restocking programmes. Juvenile giant clams exhibit chemotaxis and natural aggregative behaviour; hence, constant separation of clumped individuals in culture may not be necessary. Any one of the three possible ultimate functions of clumping highlighted by Huang et al. 2007): protection from predators, stabilisation and increased chance of fertilisation, are sufficient reasons to place clams in groups when transplanted onto a reef (Neo and Todd 2012a). Assuming that it is possible to position maricultured clams at high enough densities to encourage natural spawning and fertilisation, it is equally important to ensure that any resultant larvae have the best possible chance of finding a suitable site to settle and grow. The source-sink dynamics of giant clam larval dispersal are central to any restocking programme as nurseries should ideally be located on known source reefs so they can seed 
Fig. 5 Behaviours associated with different stages of the giant clam' life cycle

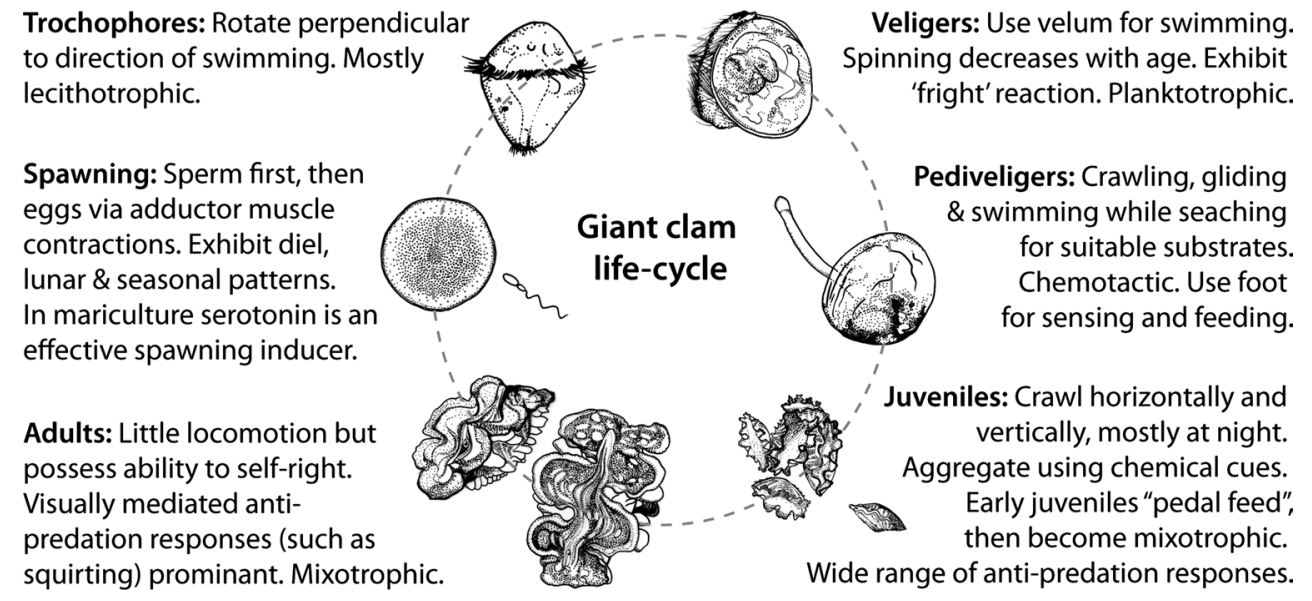

sink sites (Neo et al. 2013b). Larval dispersal patterns are usually predicted using hydrodynamic models; however, these require good behavioural data, such as the speed and swimming directionality of pelagic larvae (Neo et al. 2013b) and settlement cues (Neo et al. 2009).

Even if sources and sinks can be determined, there are still many variables that can affect the probability of larvae successfully recruiting. For example, a better understanding of how stressors such as heavy metals, low salinity and increased temperature influence the duration of pelagic stages and settlement behaviour is needed. Sediment, in particular, continues to be a major pollution issue within the ranges of most giant clam species (Todd et al. 2010). Sediment layers on substrates are known to impede invertebrate larval settlement (e.g. Rogers 1990; Te 1992) and are likely to negatively influence giant clam larvae too. Exactly how giant clam larvae behaviourally respond to sedimentcovered surfaces, however, has not been established.

Predation plays an important role in shaping bivalve mollusc communities. Visually mediated behaviours such as shadow and sight responses form a major component of the anti-predatory mechanisms employed by juvenile and adult giant clams (Wilkens 1986; Stasek 1965). Visual responses (i.e. sudden retraction of the colourful mantle and valve adduction) are likely to be more important in startling potential predators than the squirting response from either siphon apertures (Neo and Todd 2011b). Nevertheless, prolonged predatory pressures that result in repeated valve closure, and hence interrupted feeding and mantle exposure, will affect giant clam energy budgets and growth rates. Endurance of intense predation pressure and the ability of giant clams to acclimatise/habituate to repeated disturbances have implications for their survival and identification of nursery areas, but have yet to be investigated.

Giant clams are significant ecological components of coral reefs, and their decreasing populations are of concern. While existing mariculture techniques have successfully bred juvenile giant clams in their thousands, future restocking strategies should take into greater consideration their behavioural ecology (summarised in Fig. 5). Behavioural studies are a key part of fish mariculture development (e.g. Salvanes and Braithwaite 2006), and a similar approach of applied and directed research into giant clams can only benefit their conservation and management.

\section{Conclusions}

Giant clam research during the last century has focused largely on the evolution of the clam-zooxanthellae symbiosis and optimising growth rates for mariculture. For an animal that has been relatively well studied, it comes as a surprise that its behaviour has received relatively little scientific attention. Of the 100 or so publications containing behavioural data, approximately a third is related to spawning patterns. No behavioural information has been recorded for Tridacna mbalavuana, T. rosewateri, T. squamosina and $T$. noae. Much room is left for verification and quantification of the anecdotal evidence of behaviours scattered throughout the literature.

Even though the exact cues for spawning in the wild have yet to be elucidated, tridacnines appear to display diel and lunar periodicities in reproduction. General peak breeding seasons for giant clams have been established for some species, but long-term in situ monitoring of spawning behaviour and fecundity is lacking. Determining the critical size of a reproductive unit within a population would be very useful for conservation managers (Braley 1986). Information on the reproduction of giant clams in their natural environment is important for predicting their recovery rate on reefs within depleted populations (Yamaguchi 1977). To date, intragonadal injection of serotonin has proved to be most effective method for spawning induction. This technique can be optimised by timing induction to coincide with the clams' natural reproductive cycle (Ellis 1998). 
Giant clams have considerable mobility, ranging from swimming and gliding as larvae to crawling in juveniles and adults. At the pediveliger and juvenile stages, crawling and propulsion by rapid valve closure are common behaviours during the settlement period. Much of how locomotion patterns and tactic responses are shaped by environmental factors remains unknown. However, juveniles (of T. squamosa at least) move more at night than during daytime, exhibit chemotaxis and geotaxis, but they do not move towards light. The clumping behaviour described by Huang et al. (2007) should be taken into consideration when transplanting or restocking giant clams as it may increase survival. Knowledge of pelagic larval movement, such as their speed and swimming directionality, coupled with hydrodynamic modelling, would allow researchers to better predict larval dispersal and recruitment patterns.

Giant clams undergo a series of transitions in feeding strategy as they develop from larvae to juveniles (the same period during which they lose most of their locomotive capabilities) yet these shifts (e.g. to pedal feeding) are generally poorly studied. A collation of a species-specific timeline for changing modes of nutrition and locomotion should be a research priority for conservation and/or commercial mariculture programmes. In mariculture, unsuitable feeding regimes are a probable cause for high postmetamorphic mortality rates. It is essential to provide early juveniles with substrates with physical properties matching this mode of feeding, especially in terms of rugosity and food particle size (Reid and King 1988).

Because of their shell weight and/or byssal attachment, adult giant clams are unable to immediately engage in locomotory escape behaviours upon sensing, or contact with, predators. Nonetheless, they can respond to both shadows as well as tactile stimulation. Visually mediated behaviours such as shadow and sight responses form a major component of the anti-predatory mechanisms employed by both juvenile and adult giant clams (Wilkens 1986). The squirting described by Stasek (1965) and Neo and Todd (2011b) probably has multiple functions including predator deterrence and removal of rejecta from the mantle cavity. How well giant clams can 'aim' their squirts remains to be empirically tested. Visual responses, i.e. sudden contraction of the colourful mantle and valve adduction, are likely to be more important in startling potential predators than the squirting response from either siphon aperture. The effects of prolonged predatory pressures and associated valve closure on feeding behaviour and phototrophy in giant clams also have implications for their energy budget and growth rates.

The common misconception that giant clams are sedentary and simple animals stems mainly from a poor appreciation of their sensory systems and how they respond to environmental stressors such as wave action and changes in seawater properties. Distinctive righting behaviours have been described for juveniles and adults, but the effects of repeated physical disturbances, temperature fluctuations and pollution impacts are unknown. As they are expected to depress activity (Elfwing et al. 2001), more work could be done to identify synergistic effects of multiple environmental stressors on giant clam behaviour. Sensitivity thresholds to stress may be indicative of physical vigour (Waller et al. 1999) and could be a basis for selective breeding, especially for clam restocking programmes.

Knowledge on the behaviour of giant clams has applications for conservation efforts and the fine-tuning of mariculture techniques. Comparative data, both quantitative and qualitative, would help to address behavioural and ecological requirements specific to each species (Adams et al. 1988). Understanding the repertoire of giant clam behaviours will also facilitate the prediction of threshold levels for sustainable exploitation as well as recovery rates of depleted clam populations on the Indo-Pacific's disappearing reefs.

Acknowledgments Many thanks to Neo Mei Lin for the images used in Figs. 1 and 4 and Lynette Loke for the artwork used in Fig. 5. Neo Mei Lin and William Eckman read and commented on earlier drafts of this paper while many others provided advice and support, especially the team from the Experimental Marine Ecology Laboratory, National University of Singapore (NUS), Singapore. Comments from five anonymous reviewers also greatly improved the manuscript. The Tropical Marine Science Institute, NUS, kindly provided aquaria and bench space. This work was partially supported by NParks CME Grant Number R-154-000-568-490.

Open Access This article is distributed under the terms of the Creative Commons Attribution License which permits any use, distribution, and reproduction in any medium, provided the original author(s) and the source are credited.

\section{References}

Accordi G, Brilli M, Carbone F, Voltaggio M (2010) The raised coral reef complex of the Kenyan coast: Tridacna gigas U-series dates and geological implications. J Afr Earth Sci 58:97-114

Adams TJH, Lewis AD, Ledua E (1988) Natural population dynamics of Tridacna derasa in relation to reef reseeding and mariculture. In: Copland JW, Lucas JS (eds) Giant clams in Asia and the Pacific. Australian Centre for International Agricultural Research, Canberra, pp 78-81

Alcala AC (1986) Distribution and abundance of giant clams (Family Tridacnidae) in the South-Central Philippines. Silliman J 33:1-9

Alcala AC, Solis EP, Alcazar SN (1986) Spawning, larval rearing and early growth of Hippopus hippopus (Linn) (Bivalvia: Tridacnidae). Silliman J 33:45-53

Alcazar SN (1986) Observations on predators of giant clams (Bivalvia: Family Tridacnidae). Silliman Journal 33:54-57

Alcazar SN (1988) Spawning and larval rearing of tridacnid clams in the Philippines. In: Copland JW, Lucas JS (eds) Giant clams in Asia and the Pacific. Australian Centre for International Agricultural Research, Canberra, pp 125-128 
Alcazar SN, Solis EP (1986) Spawning, larval rearing and early growth of Tridacna maxima (Röding) (Bivalvia: Tridacnidae). Silliman J 33:65-73

Alcazar SN, Solis EP, Alcala AC (1987) Serotonin-induced spawning and larval rearing of the China Clam, Hippopus porcellanus Rosewater (Bivalvia: Tridanidae). Aquaculture 66:359-368

Ansell AD (1967) Leaping and other movements in some Cardiid bivalves. Anim Behav 15:421-426

Atoda K (1953) The larval and post-larval development of the reef-building corals. Sci Rep Tôhoku Univ (Series 4, Biol) 20:105-121

Bayne BL (1965) Growth and delay of metamorphosis of the larvae of Mytilus edulis (L.). Ophelia 2:1-47

Bayne BL (1971a) Some morphological changes that occur at the metamorphosis of the larvae of Mytilus edulis. In: Crisp DJ (ed) The fourth European marine biology symposium. Cambridge University Press, Cambridge, pp 259-281

Bayne BL (1971b) Ventilation, the heart beat and oxygen uptake by Mytilus edulis L. in declining oxygen tension. Comp Biochem Physiol 40A:1065-1085

Beckvar N (1981) Cultivation, spawning, and growth of the giant clams Tridacna gigas, T. derasa and T. squamosa in Palau, Caroline Islands. Aquaculture 24:21-30

Bell ID (1999) Reducing the costs of restocking giant clams in Solomon Islands. Coral Reefs 18:326

Bertness MD, Grosholz E (1985) Population dynamics of the ribbed mussel, Geukensia demissa: the costs and benefits of an aggregated distribution. Oecologia 67:192-204

Blidberg E (2004) Effects of copper and decreased salinity on survival rate and development of Tridacna gigas larvae. Mar Environ Res 58:793-797

Blidberg E, Elfwing T, Tedengren M (1999) Physiological responses of the fluted giant clam, Tridacna squamosa, exposed to decreased irradiance and reduced salinity. Phuket Mar Biol Cent Spec Publ 19:85-91

Blidberg E, Elfwing T, Plantman P, Tedengrem M (2000) Water temperature influences on physiological behaviour in three species of giant clams (Tridacnidae). In: Proceedings of the ninth international coral reef symposium, Bali, Indonesia, vol 1, pp $561-565$

Bonham K (1965) Growth rate of giant clam Tridacna gigas at Bikini Atoll as revealed by radioautography. Science 149:300-302

Braley RD (1984) Reproduction in the giant clams Tridacna gigas and T. derasa in situ on the North-Central Great Barrier Reef, Australia, and Papua New Guinea. Coral Reefs 3:221-227

Braley RD (1985) Serotonin-induced spawning in giant clams (Bivalvia: Tridanidae). Aquaculture 47:321-325

Braley RD (1986) Reproduction and recruitment of giant clams and some aspects of their larval and juvenile biology. $\mathrm{PhD}$ thesis. University of New South Wales, Australia, $297 \mathrm{pp}$

Braley RD (1987) Distribution and abundance of the giant clams Tridacna gigas and T. derasa on the Great Barrier Reef. Micronesia 20:215-223

Brock J (1888) On the so-called eyes of Tridacna and the occurrence of pseudochlorophyll-corpuscles in the vascular system of the Lamellibranchiata (Translated by W.S. Dallas from Zeitschrift für wissenschaftliche Zoologie, XLVI, 270-287) Ann Mag Nat Hist Ser 6(1):435-452

Bustard R (1972) Sea turtles: natural history and conservation. Collins, London, p 200

Cabaitan PC, Gomez ED, Alino PM (2008) Effects of coral transplantation and giant clam restocking on the structure of fish communities on degraded patch reefs. J Exp Mar Biol Ecol 357:85-98

Calumpong HP (ed) (1992) The giant clam: an ocean culture manual. ACIAR Monograph, pp 68
Calumpong HP, Estacion JS, Lucañas JR, Apao AB (2003) Survival, settlement and growth of the fluted giant clam, Tridacna squamosa on different substrates. Philipp Sci 40:101-110

Carriker MR (1990) Functional significance of the pediveliger in bivalve development. In: Morton B (ed) The Bivalvia: proceedings of a memorial symposium in honour of sir Charles Maurice Yonge (1899-1986) at the 9th international malacological congress 1986, Edinburgh, Scotland. Hong Kong University Press, Hong Kong, pp 267-282

Chan KR, Todd PA, Chou LM (2009) An allometric analysis of juvenile fluted giant clam shells (Tridacna squamosa L.). J Conch 39:621-625

Comfort A (1957) The duration of life in molluscs. Proc Malacol Soc Lond 32:219-241

Courtois de Vicose G (2000) Survival rates of Tridacna squamosa larvae exposed to different substrates: impact of substrates colonised by crustose coralline algae. In: Abstracts of 9th international coral reef symposium, Bali, Indonesia, p 301

Cranfield HJ (1973) Observations on the behaviour of the pediveliger of Ostrea edulis during attachment and cementing. Mar Biol 22:203-209

Crawford CM, Nash WJ, Lucas JS (1986) Spawning induction, and larval and juvenile rearing of giant clam, Tridacna gigas. Aquaculture 58:281-295

Culliney JL (1974) Larval development of the giant scallop Placopecten magellanicus (Gmelin). Biol Bull 147:321-332

DeBoer TS, Baker AC, Erdmann MV, Ambariyanto, Jones PR, Barber PH (2012) Patterns of Symbionidium distribution in three giant clam species across the biodiverse Bird's Head region of Indonesia. Mar Ecol Prog Ser 444:117-132

Downing JA, Rochon Y, Perusse M, Harvey H (1993) Spatial aggregation, body size, and reproductive success in the freshwater mussel Elliptio complanata. J North Am Benthol Soc 12:148-156

Dumas P, Tiavouane J, Senia J, Willam A, Dick L, Fauvelot C (2014) Evidence of early chemotaxis contributing to active habitat selection by the sessile giant clam Tridacna maxima. J Exp Mar Biol Ecol 452:63-69

Eckman W, Vicentuan-Cabaitan K, Todd PA (2014) Observations on the hyposalinity tolerance of fluted giant clam (Tridacna squamosal, Lamarck 1819) larvae. Nat Singap 7:111-116

Elfwing T, Plantman P, Tedengren M, Wijnbladh E (2001) Responses to temperature, heavy metal and sediment stress by the giant clam Tridacna squamosa. Mar Freshw Behav Physiol 34:239-248

Elfwing T, Blidberg E, Tedengren M (2002) Physiological responses to copper in giant clams: a comparison of two methods in revealing effects on photosynthesis in zooxanthellae. Mar Environ Res 54:147-155

Elfwing T, Blidberg E, Sison M, Tedengren M (2003) A comparison between sites of growth, physiological performance and stress responses in transplanted Tridacna gigas. Aquaculture 219:815-828

Ellis S (1998) Spawning and early larval rearing of giant clams (Bivalvia: Tridacnidae). Cent Trop Subtrop Aquac 130:1-55

Fankboner PV (1971) Self righting by tridacnid clams. Nature 230:579

Fankboner PV (1981) Siphonal eyes of giant clams and their relationship to adjacent zooxanthellae. Veliger 23:245-249

Fankboner PV, Reid RGB (1990) Nutrition in giant clams (Tridacnidae). In: Morton B (ed) The Bivalvia: proceedings of a memorial symposium in honour of Sir Charles Maurice Yonge (18991986) at the 9th international malacological congress 1986, Edinburgh, Scotland. Hong Kong University Press, Hong Kong, pp 195-209

Fitt WK (1993) Nutrition of giant clams. In: Fitt WK (ed) Biology and mariculture of giant. ACIAR proceedings no. 47, Australian 
Centre for international agricultural research, Canberra, pp $31-40$

Fitt WK, Trench RK (1981) Spawning, development, and acquisition of zooxanthellae by Tridacna squamosa (Mollusca, Bivalvia). Biol Bull 161:213-235

Fitt WK, Fisher CR, Trench RK (1984) Larval biology of tridacnid clams. Aquaculture 39:181-195

Fujikura K, Amaki K, Barry JP, Fujiwara Y, Furushima Y, Iwase R, Yamamoto H, Maruyama T (2007) Long-term in situ monitoring of spawning behavior and fecundity in Calyptogena spp. Mar Ecol Prog Ser 333:185-193

Gallucci VF, Gallucci BB (1982) Reproduction and ecology of the hermaphroditic cockle Clinocardium nuttallii (Bivalvia: Cardiidae) in Garrison Bay. Mar Ecol Prog Ser 7:137-145

Gilmour THJ (1964) The structure, ciliation and function of the lipapparatus of Lima and Pecten (Lamellibranchia). J Mar Biol Assoc UK 44:485-498

Glynn PW (1993) Coral reef bleaching: ecological perspectives. Coral Reefs 12:1-17

Gomez ED, Mingoa-Licuanan SS (1998) Mortalities of giant clams associated with unusually high temperatures and coral bleaching. Reef Encount 24:23

Gomez ED, Mingoa-Licuanan SS (2006) Achievements and lessons learned in restocking giant clams in the Philippines. Fish Res 80:46-52

Gomez ED, Mingoa-Licuanan S, Roa-Quaoit HA (2000) The culture of the true giant clam Tridacna gigas for conservation in the Philippines. Conference proceedings: special session on mollusk research in Asia. University of the Philippines at Los Baños, Philippines, pp 159-163

Govan H, Fabro LY, Ropeti E (1993) Controlling predators of cultured Tridacnid clams. In: Fitt WK (ed) Biology and mariculture of giant clams. ACIAR proceedings no. 47, Australian centre for international agricultural research, Canberra, pp 111-118

Guest JR, Todd PA, Goh E, Sivaloganathan B, Reddy KP (2008) Can giant clam (Tridacna squamosa) populations be restored on Singapore's heavily impacted coral reefs? Aquat Conserv Mar Freshw Ecosyst 18:570-579

Gwyther J, Munro JL (1981) Spawning induction and rearing of larvae of tridacnid clams (Bivalvia: Tridacnidae). Aquaculture 24:197-217

Hardy JT, Hardy SA (1969) Ecology of Tridacna in Palau. Pac Sci 23:467-472

Hart AM, Bell JD, Foyle TP (1998) Growth and survival of the giant clams, Tridacna derasa, T. maxima and T. crocea, at village farms in the Solomon Islands. Aquaculture 165:203-220

Hartman MC, Pratt I (1976) Infection of the heart cockle, Clinocardium nuttalli, from Yaquina Bay, Oregon, with an endosymbiotic alga. J Invert Pathol 28:291-299

Heslinga GA (1989) Biology and culture of the giant clams. In: Menzi J, Castagna M (eds) Clam culture in North America. Elsevier, Amsterdam, pp 293-322

Heslinga GA, Perron FE, Orak O (1984) Mass culture of giant clams (F. Tridacnidae) in Palau. Aquaculture 39:197-215

Heslinga GA, Watson T, Isamu T (1990) Giant clam farming. Pacific Fisheries Development Foundation (NMF/NOAA), Honolulu

Hester FJ, Jones EC (1974) A survey of giant clams, Tridacnidae, on Helen Reef, a Western Pacific Atoll. Mar Fish Rev 36:17-22

Hickman RW, Gruffydd LLD (1971) The histology of the larvae of Ostrea edulis during metamorphosis. In: Crisp DJ (ed) The fourth European marine biology symposium. Cambridge University Press, Cambridge, pp 281-294

Hollingsworth LL, Kinzie RA, Lewis TD, Krupp DA, Leong J-AC (2005) Phototaxis of motile zooxanthellae to green light may facilitate symbiont capture by coral larvae. Coral Reefs 24:523
Huang D, Todd PA, Guest JR (2007) Movement and aggregation in the fluted giant clam (Tridacna squamosa L.). J Exp Mar Biol Ecol 342:269-281

Huelsken T, Keyse J, Liggins L, Penny S, Treml EA, Riginos C (2013) A novel widespread cryptic species and phylogeographic patterns within several giant clam species (Cardiidae: Tridacna) from the Indo-Pacific Ocean. PLoS ONE 8:e80858

Husin NM, Yasin Z, Tan AS-H (2001) Shell morphology and culture of Tridacna squamosa larvae (Bivalvia: Tridacnidae). Phuket Mar Biol Cent Spec Publ 25:169-172

Hviding E (1993) The Rural Context of Giant Clam Mariculture in the Solomon Islands: An Anthropological Study. International Center for Living Aquatic Resources Management, Manila, $p$ 93

Idjadi JA, Edmunds PJ (2006) Scleractinian corals as facilitators for other invertebrates on a Caribbean reef. Mar Ecol Prog Ser 319:117-127

Jameson SC (1976) Early life history of the giant clams Tridacna crocea Lamarck, Tridacna maxima (Röding), and Hippopus hippopus (Linnaeus). Pac Sci 30:219-233

Kawaguti S (1950) Observations on the heart shell, Corculum cardissa (L.) and its associated zooxanthellae. Pac Sci 4:43-49

Kawaguti S (1968) Electron microscopy on zooxanthellae in the mantle and gill of the heart shell. Biol J Okayama Univ 14:1-12

Kirkendale L (2009) Their day in the sun: molecular phylogenetics and origin of photosymbiosis in the 'other' group of photosymbiotic marine bivalves (Cardiidae: Fraginae). Biol J Linn Soc 97:448-465

Klumpp DW, Lucas JS (1994) Nutrition of the giant clams Tridacna tevoroa and T. derasa from Tonga: influence of light on filterfeeding and photosynthesis. Mar Ecol Prog Ser 107:147-156

Krause J, Ruxton GD (2002) Living in groups. Oxford University Press, New York, p 228

LaBarbera M (1974) Calcification of the first larval shell of Tridacna squamosa (Tridacnidae: Bivalvia). Mar Biol 25:233-238

LaBarbera M (1975) Larval and post-larval development of the giant clams Tridacna maxima and Tridacna squamosa (Bivalvia: Tridacnidae). Malacologia 15:69-79

Land MF (1968) Functional aspects of the optical and retinal organization of the mollusc eye. Symp Zool Soc Lond 23:75-96

Land MF (2003) The spatial resolution of the pinhole eyes of giant clams (Tridacna maxima). Proc Roy Soc Lond B 270:185-188

Lane DJW, Nott JA (1975) A study of the morphology, fine structure and histochemistry of the foot of the pediveliger of Mytilus edulis L. J Mar Biol Assoc UK 55:477-495

Lang JC, Chornesky EA (1990) Competition between scleractinian reef corals: a review of mechanisms and effects. In: Dubunsky Z (ed) Ecosystems of the world, vol 25., Coral ReefsElsevier, Amsterdam, pp 209-251

Lin AYM, Meyers MA, Vecchio KS (2006) Mechanical properties and structure of Strombus gigas, Tridacna gigas and Haliotis rufescens sea shells: a comparative study. Mater Sci Eng C 26:1380-1389

Ling H, Todd PA, Chou LM, Yap VB, Sivaloganathan B (2008) The defensive role of scutes in juvenile fluted giant clams (Tridacna squamosa). J Exp Mar Biol Ecol 359:77-83

Loosanoff VL, Davis HC (1963) Rearing of bivalve molluscs. In: Russell FS (ed) Advances in marine biology, vol 1. Academic Press, New York, pp 1-136

Lucas JS (1988) Giant clams: Description, distribution and life history. In: Copland JW, Lucas JS (eds) Giant clams in Asia and the Pacific. Australian Centre for International Agricultural Research, Canberra, pp 21-32

Lucas JS (1994) The biology, exploitation, and mariculture of giant clams (Tridacnidae). Rev Fish Sci 2:181-223 
Lucas JS, Nash WJ, Crawford CM, Braley RD (1989) Environmental influences on growth and survival during the ocean-nursery rearing of giant clams, Tridacna gigas (L.). Aquaculture $80: 45-61$

Lucas JS, Ledua E, Braley RD (1991) Tridacna tevoroa Lucas, Ledua and Braley: a recently described species of giant clam (Bivalvia; Tridacidae) from Fiji and Tonga. Nautilus 105:92-103

Lund-Hansen LC, Petersson M, Nurjaya W (1999) Vertical sediment fluxes and wave-induced sediment resuspension in a shallowwater coastal lagoon. Estuar Coast 22:39-46

Lyons BP, Pascoe CK, McFadzen IR (2002) Phototoxicity of pyrene and benzo[a]pyrene to embryo-larval stages of the Pacific oyster Crassostrea gigas. Mar Environ Res 54:627-631

Malham SK, Hutchinson TH, Longshaw M (2012) A review of the biology of European cockles (Cerastoderma spp.). J Mar Biol Assoc UK 92:1563-1577

Marois R, Carew TJ (1990) The gastropod nervous system in metamorphosis. J Neurobiol 21:1053-1071

McMichael DF (1974) Growth rate, population size, and mantle colouration in the small giant clam Tridacna maxima (Röding), at One Tree Island, Capricon Group, Queensland. Proc 2nd Int Coral Reef Symp 1:241-254

Mies M, Braga F, Scozzafave MS, Lemos D, Sumida PYG (2012) Early development, survival and growth rates of the giant clam Tridacna crocea (Bivalvia: Tridacnidae). Braz J Oceanogr 60:129-135

Mingoa-Licuanan SS, Gomez ED (2002) Giant clam conservation in Southeast Asia. Trop Coasts 3:24-56

Mingoa-Licuanan SS, Lucas JS (1995) Bivalves that "feed" out of water: phototrophic nutrition during emersion in the giant clam, Tridacna gigas Linne. J Shellfish Res 14:283-286

Morton JE (1967) Molluscs, 4th edn. Hutchinson University Library, London

Morton B (1978) The diurnal rhythm and the processes of feeding and digestion in Tridacna crocea (Bivalvia: Tridacnidae). J Zool 185:371-387

Munro JL (1993) Giant clams. In: Wright A, Hill L (ed) Nearshore marine resources of the South Pacific: information for fisheries development and management. Forum Fisheries Agency, Institute of Pacific Studies, and International Centre for Ocean Development, pp 431-450

Munro JL, Gwyther J (1981) Growth rates and maricultural potential of tridacnid clams. In: Proceedings of the 4th international coral reef symposium vol 2, pp 633-636

Munro JL, Heslinga GA (1983) Prospects for the commercial cultivation of giant clams (Bivalvia: Tridacnidae). In: Proceedings of the Gulf and Caribbean Fisheries Institute, vol 35, pp 122-134

Munro JL, Nash WJ (1985) A bibliography of giant clams (Bivalvia: Tridacnidae). International center for living aquatic resources management, Manila, Phillipines. International Centre for Ocean Development, pp 710

Munro PE, Beard JH, Lacanienta E (1983) Investigations on the substance which causes sperm release in tridacnid clams. Comp Biochem Physiol 74C:219-223

Neo ML (2009) Defence mechanisms in juvenile fluted giant clams (Tridacna squamosa). Honours thesis (unpublished). National University of Singapore, Singapore

Neo ML, Todd PA (2011a) Predator-induced changes in fluted giant clam (Tridacna squamosa) shell morphology. J Exp Mar Biol Ecol 397:21-26

Neo ML, Todd PA (2011b) Quantification of water squirting by juvenile fluted giant clams (Tridacna squamosa L.). J Ethol 29:85-91

Neo ML, Todd PA (2012a) Giant clams (Mollusca: Bivalvia: Tridacninae) in Singapore: history, research and conservation. Raff Bull Zool 25:67-78
Neo ML, Todd PA (2012b) Population density and genetic structure of the giant clams Tridacna crocea and T. squamosa on Singapore's reefs. Aquat Biol 14:265-275

Neo ML, Todd PA, Teo SL, Chou LM (2009) Can artificial substrates enriched with crustose coralline algae enhance larval settlement and recruitment in the fluted giant clam (Tridacna squamosa). Hydrobiologia 625:83-90

Neo ML, Todd PA, Chou LM, Teo SL (2011) Spawning induction and larval development in the fluted giant clam, Tridacna squamosa (Bivalvia: Tridacnidae). Nat Singap 4:157-161

Neo ML, Todd PA, Teo SL, Chou LM (2013a) The effects of diet, temperature and salinity on survival of larvae of the fluted giant clam, Tridacna squamosa. J Conch 4:369-376

Neo ML, Erftemeijer PA, van Beek JKL, van Maren DS, Teo SL, Todd PA (2013b) Recruitment constraints in Singapore's fluted giant clam (Tridacna squamosa) populations-a dispersal model approach. PLoS ONE 8:e58819

Newman WA, Gomez ED (2000) On the status of giant clams, relics of Tethys (Mollusca: Bivalvia: Tridacnidae). In: Proceedings of the ninth international coral reef symposium. Bali, Indonesia, vol 2, pp 927-936

Norton JH, Jones GW (1992) The giant clam: an anatomical and histological atlas. Australian Center for International Agricultural Research (ACIAR) Monograph Series, Canberra, p 142

Othman AS, Goh AS, Todd PA (2010) The distribution and status of giant clams (family Tridacnidae) - a short review. Raff Bull Zool 58:103-111

Peck LS, Webb KE, Bailey DM (2004) Extreme sensitivity of biological function to temperature in Antarctic marine species. Funct Ecol 18:625-630

Peters EC, Gassman NJ, Firman JC, Richmond RH, Power EA (1997) Ecotoxicology of marine tropical ecosystems. Environ Toxicol Chem 16:12-40

Petersen D, Laterveer M, Schuhmacher H (2005a) Innovative substrate tiles to spatially control larval settlement in coral culture. Mar Biol 146:937-942

Petersen D, Laterveer M, Schuhmacher H (2005b) Spatial and temporal variation in larval settlement of reefbuilding corals in mariculture. Aquaculture 249:317-327

Purchon RD (1955a) A note on the biology of Tridacna crocea Lam. Proc Malacol Soc Lond 31:95-110

Purchon RD (1955b) The structure and function of the British Pholadidae (rock-boring Lamellibranchia). Proc Zool Soc Lond 124:859-911

Purchon RD (ed) (1977) The biology of the Mollusca, 2nd edn. Pergamon Press, New York, p 560

Raven CP (1966) Morphogenesis: The analysis of molluscan development, 2nd edn. Pergamon Press, New York, p 365

Reid RGB, King JJ (1988) Postmetamorphic feeding in clams: relevance to Tridacnidae. In: Copland JW, Lucas JS (eds) Giant clams in Asia and the Pacific. Australian Centre for International Agricultural Research, Canberra, pp 161-165

Reid RGB, Fankboner PV, Brand DG (1984) Studies on the physiology of the giant clam Tridacna gigas Linne-I. Feeding and digestions. Comp Biochem Physiol 78:95-101

Reid RGB, McMahon RF, Foighil DÓ, Finnigan R (1992) Anterior inhalant currents and pedal feeding in bivalves. Veliger 35:93-104

Reimer O, Tedengren M (1997) Predator-induced changes in byssal attachment, aggregation and migration in the blue mussel, Mytilus edulis. Mar Freshw Behav Physiol 30:251-266

Richardson CA, Ibarrola I, Ingham RJ (1993) Emergence pattern and spatial distribution of the common cockle Cerastoderma edule. Mar Ecol Prog Ser 99:71-81

Rodríguez SR, Ojeda FP, Inestrosa NC (1993) Settlement of benthic marine invertebrates. Mar Ecol Prog Ser 97:193-207 
Rogers CS (1990) Responses of coral reefs and reef organisms to sedimentation. Mar Ecol Prog Ser 62:185-202

Romano C, SarÀ G, Salvo G, Bishop J, Mazzola A, Widdows J (2011) Effect of the presence of the shore crab, Carcinus maenas, on burrowing behaviour and clearance rate of the common cockle, Cerastoderma edule. Mar Biol 158:2685-2694

Rosewater J (1965) The family Tridacnidae in the Indo-Pacific. IndoPacific Mollusca 1:347-396

Rosewater J (1966) The giant clams (Tridacnidae). Aust Nat Hist $15: 250-256$

Salvanes AGV, Braithwaite VA (2006) The need to understand the behaviour of fish we rear for mariculture or for restocking. ICES J Mar Sci 63:346-354

Seed R (1969) The ecology of Mytilus edulis L. (Lamellibranchiata) on exposed rocky shores. I. Breeding and settlement. Oecologia 3:277-316

Shelley CC, Southgate PC (1988) Reproductive periodicity and morphometry of Hippopus hippopus and Tridacna crocea. In: Copland JW, Lucas JS (eds) Giant clams in Asia and the Pacific. Australian Centre for International Agricultural Research, Canberra, pp 86-88

Soo P, Todd PA (2012) Nocturnal movement and possible geotaxis in the fluted giant clam (Tridacna squamosa). In: Contributions to marine science. A commemorative volume celebrating 10 years of research on St John's Island. Tropical Marine Science Institute, National University of Singapore, pp 159-162

Soo P, Soo E, Todd PA (2011) An insight into the giant clam trade in Singapore. Innov Mag 10:28-31

Stasek CR (1962) The form, growth and evolution of the Tridacnidae (Giant Clams). Arch Zool Exp Gen 101:1-40

Stasek CR (1965) Behavioural adaptation of the giant clam Tridacna maxima to the presence of grazing fishes. Veliger 8:29-35

Stat M, Gates RD (2011) Clade D Symbiodinium in scleractinian corals: A "nugget" of hope, a selfish opportunist, an ominous sign, or all of the above? J Mar Biol, 2011, Article ID 730715. doi:10.1155/2011/730715

Stephenson A (1934) The breeding of reef animals, Part II. Invertebrates other than corals. Scientific report Great Barrier Reef expedition 1928-1929, vol 3, pp 247-272

Streamer M, Griffiths DJ, Thinh L-V (1988) The products of photosynthesis by zooxanthellae (Symbiodinium microadriaticum) of Tridacna gigas and their transfer to the host. Symbiosis 6:237-252

Su Y, Hung J-H, Kubo H, Liu L-L (2014) Tridacna noae (Röding, 1798) - a valid giant clam species separated from T. maxima (Röding, 1798) by morphological and genetic data. Raff Bull Zool 62:124-135

Suzuki Y (1998) Preliminary studies on locomotion and burrowing by juvenile boring clam, Tridacna crocea. Naga ICLARM Q 21:31-35

Svane I (1996) Some recent advances in the studies on biology of giant clams (Tridacnidae). Phuket Mar Biol Cent Spec Publ 16:221-241

Tan AS-H, Yasin Z (1998) The reproductive cycle of Tridacna squamosa and Tridacna maxima at Rengis Island (Tioman island), Malaysia. Phuket Mar Biol Cent Spec Publ 18:107-112

Tan AS-H, Yasin Z (2001a) Factors affecting the dispersal of Tridacna squamosa larvae and gamete material in the Tioman Archipelago, the South China Sea. Phuket Mar Biol Cent Spec Publ 25:349-356

Tan AS-H, Yasin Z (2001b) Shell morphology and culture of Tridacna squamosa larvae (Bivalvia: Tridacnidae). Phuket Mar Biol Cent Spec Publ 25:169-172
Tan AS-H, Yasin Z (2003) Status of giant clams in Malaysia. SPC Trochus Inf Bull 10:9-10

Te FT (1992) Response to higher sediment loads by Pocillopora damicornis planulae. Coral Reefs 11:131-134

Tedengren M, Blidberg E, Elfwing T (2000) The effects of different light intensities on photosynthesis and filter-feeding of the giant clam, Tridacna squamosa. In: Mollusk research in Asia, Proceedings of the fifth Asian fishery forum 1998, Chiang Mai, Thailand, pp 165-171

Thorson G (1950) Reproductive and larval ecology of marine bottom invertebrates. Biol Rev 25:1-45

Todd PA, Lee JH, Chou LM (2009) Polymorphism and crypsis in the boring giant clam (Tridacna crocea): potential strategies against visual predators. Hydrobiologia 635:37-43

Todd PA, Ong X, Chou LM (2010) Impacts of pollution on marine life in Southeast Asia. Biodivers Conserv 19:1063-1082

Toonen RJ, Nakayama T, Ogawa T, Rossiter A, Delbeek JC (2012) Growth of cultured giant clams (Tridacna spp.) in low $\mathrm{pH}$, highnutrient seawater: species-specific effects of substrate and supplemental feeding under acidification. J Mar Biol Assoc UK 92:731-740

Trench RK, Wethey DS, Porter JW (1981) Observations on the symbiosis with zooxanthellae among the tridacnidae (Mollusca, Bivalvia). Biol Bull 161:180-198

Vaillant L (1865) Recherches sur la Famille des Tridacnidés. Ann Sci Nat Zool 5:64-172

Vicentuan-Cabaitan K, Neo ML, Eckman W, Teo SL, Todd PA (2014) Giant clams shells host a multitude of epibionts. Bull Mar Sci 90:795-796

Wabnitz C, Taylor M, Green E, Razak T (2003) From ocean to aquarium. The global trade in marine ornamental species. UNEPWCMC, Cambridge, p 66

Wada SK (1952) Protandric functional hermaphroditism in the tridanid clams. Oceanogr Mag 4:23-30

Wada SK (1954) Spawning in the tridacnid clams. Jpn J Zool $11: 273-285$

Waller DL, Gutreuter S, Rach JJ (1999) Behavioral responses to disturbance in freshwater mussels with implications for conservation and management. J North Am Benthol Soc 18:381-390

Watzin MC (1986) Larval settlement into marine soft-sediment systems: interactions with the meiofauna. J Exp Mar Biol Ecol 98:65-113

Wilkens LA (1981) Neurobiology of the scallop. I. Starfish-mediated escape behaviours. Proc Roy Soc Lond B 211:341-372

Wilkens LA (1984) Ultraviolet sensitivity in hyperpolarizing photoreceptors of the giant clam Tridacna. Nature 309:446-448

Wilkens LA (1986) The visual system of the giant clam Tridacna: behavioral adaptations. Biol Bull 170:393-408

Yamaguchi M (1977) Conservation and cultivation of giant clams in the tropical pacific. Biol Conserv 11:13-20

Yonge CM. (1936) Mode of life feeding, digestion and symbiosis with zooxanthellae in the Tridanidae. Scientific report of the Great Barrier Reef expedition 1928-1929, vol 1, pp 283-321

Yonge CM (1960) Oysters. Collins, London, p 209

Yonge CM (1974) Coral reefs and molluscs. Trans Roy Soc Edin 69:147-166

Yonge CM (1975) Giant clams. Sci Am 232:96-105

Yonge CM (1982) Functional morphology and evolution in the Tridacnidae (Mollusca: Bivalvia: Cardiacea). Rec Aust Mus 33:735-777

Zahl PA, McLaughlin JJA (1959) Studies in marine biology. IV. On the role of algal cells in the tissues of marine invertebrates. J Protozool 6:344-352 